
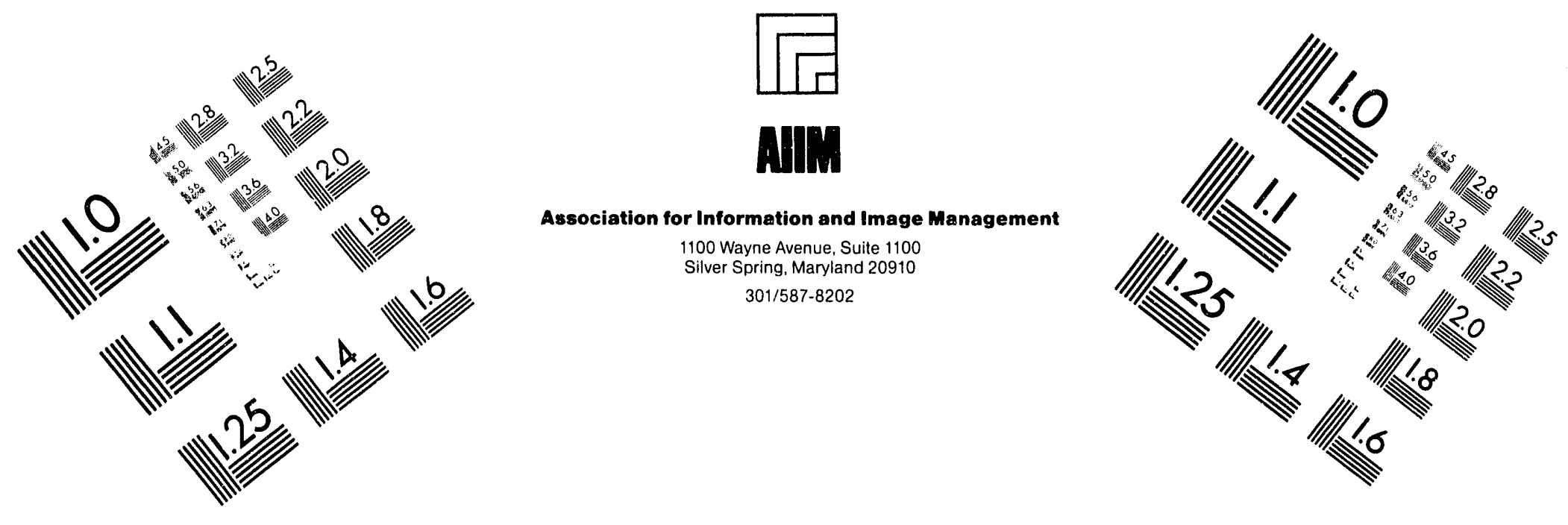

\title{
Centimeter
}

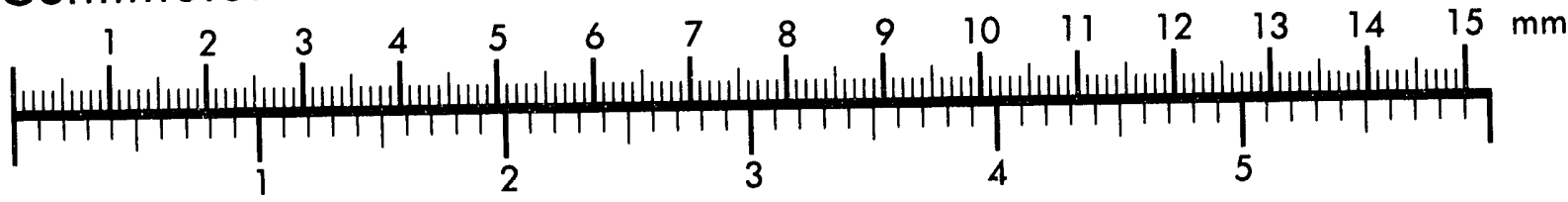
Inches
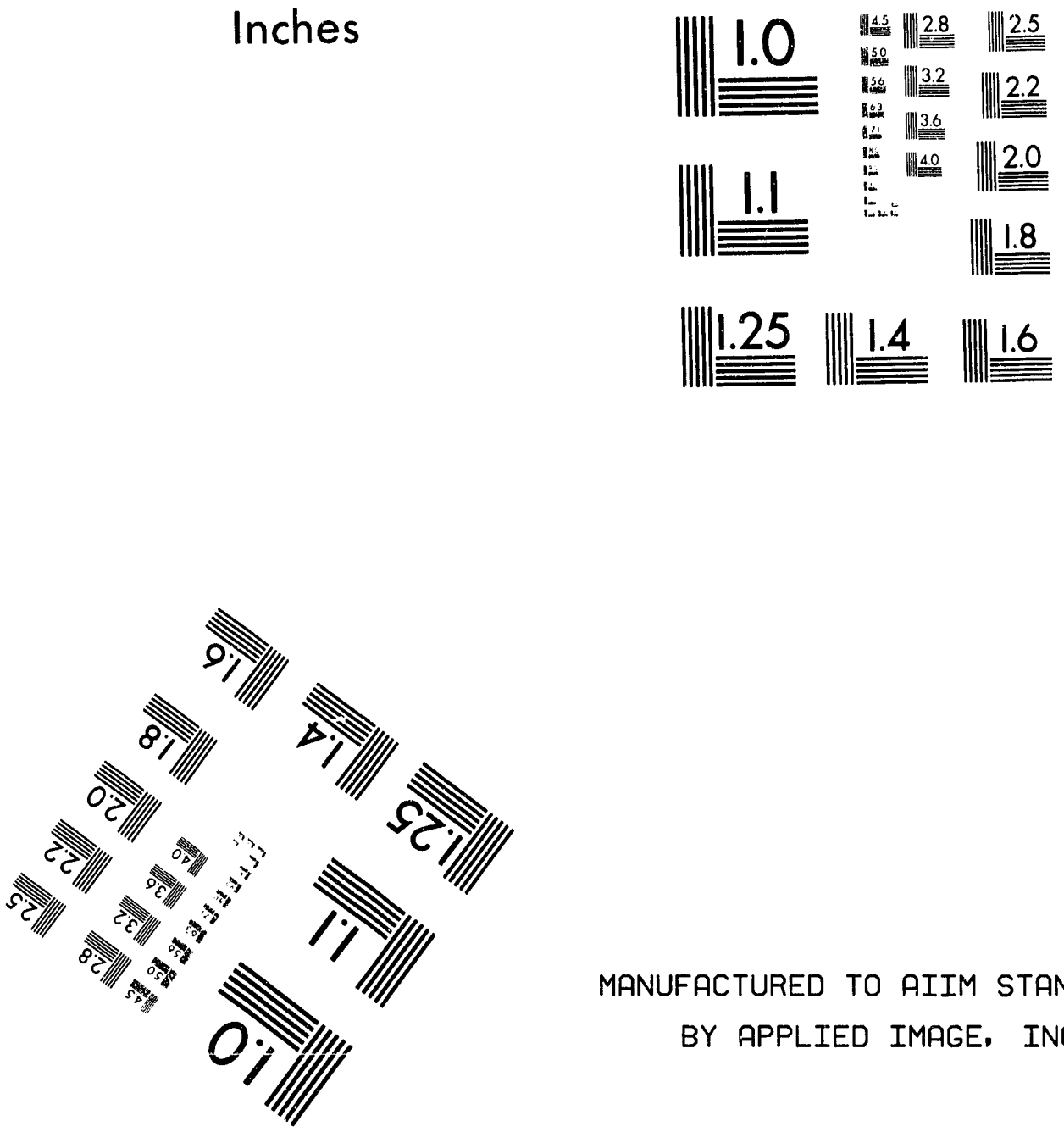

MANUFACTURED TO AIIM STANDARDS

BY APPLIED IMAGE, INC.

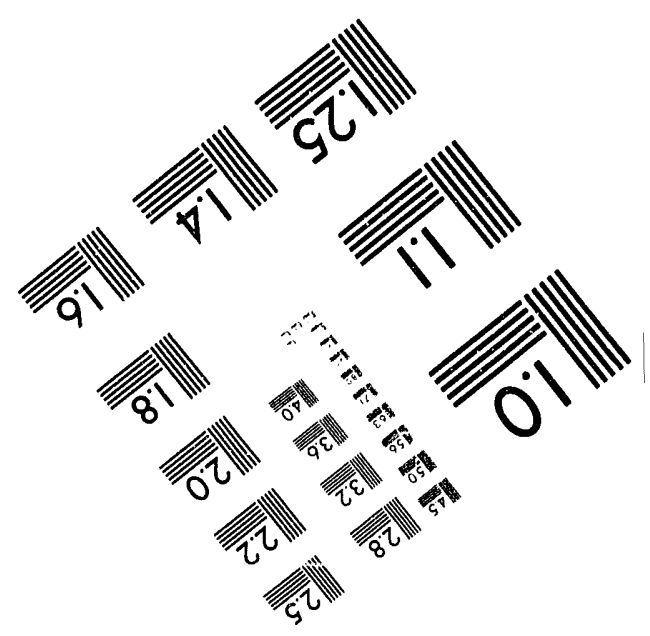



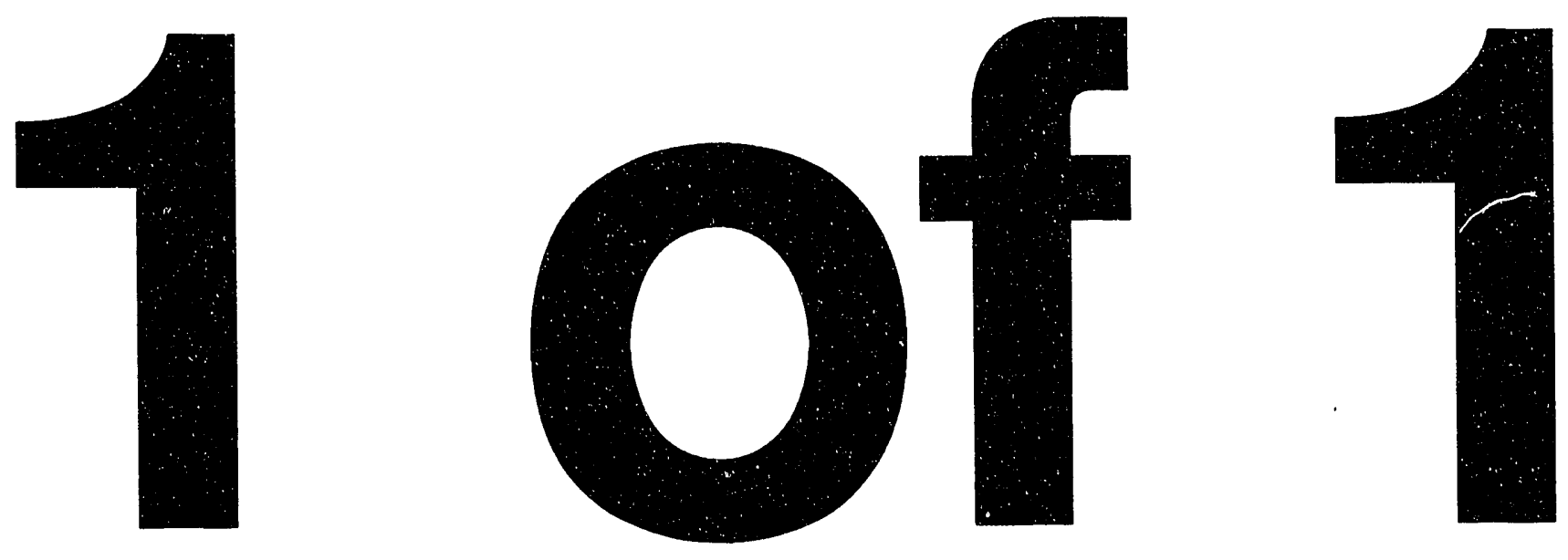
NRTSC

NUCLEAR REACTOR TECHNOLOGY

WSRC-TR-92-335

AND SCIENTIFIC COMPUTATIONS

KEYWORDS: $\quad$ SEPTIFOIL

POISON PLATE

ROTAMETER

UNIVERSAL SLEEVE HOUSING (USH)

RETENTION: PERMANENT

\section{USH Cooling Via Septifoils (U)}

by

Thomas L. Spatz

ISSUED: November 1992

Westinghouse Savannah River Corporation Savannah River Technology Center Aiken,SC 29808

RECEIVED

JUN 091993

OSTI
Property of the U.S. Department of Energy under Contract DE-AC09-89SR18035

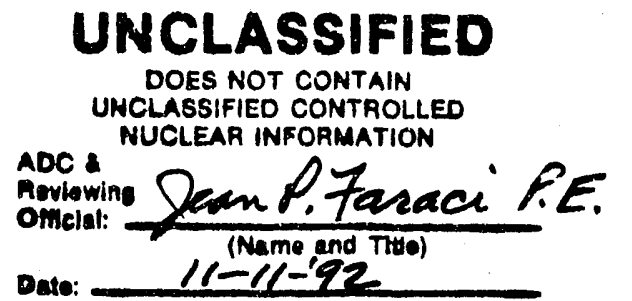




DISCLAIMER
This report was prepared by the Westinghouse Savannah River
Corporation (Westinghouse) for the Unlted States Department of Energy
under Contract DE-AC09-89SR18035 and Is an account of work
performed under that Contract. Nelther the United States, the United
States Department of Energy, nor Westinghouse, nor any of their
employees, makes any warranty, expressed or Implled, or assumes any
legal liability or responsibllity for the accuracy, completeness, or
usefulness of any Informatlon, apparatus, product, or process disclosed
herein, or represents that Its use will not infringe privately owned rights.
Reference herein to any specific commerclal product, process or service
by trade name, mark, manufacturer, or otherwise does not necessarlly
constltute or Imply endorsement, recommendatlon, or favoring of same
by Westinghouse or by the United States Government or any agency
thereof. The vlews and opinlons of authors expressed herein do not
necessarlly state or reflect those of the United States Government or any
agency thereof.


DOCUMENT:

TITLE:

REVISION NUMBER:

TASK:

TASK NUMBER:
WSRC-TR-92-335

USH Cooling Via Septifoils

0 USH COOLING VIA SEPTIFOIL: REDUCED FLOW

92-062-1

\title{
USH Cooling Via Septifoils (U)
}

\author{
by
}

Thomas L. Spatz

\section{APPROVALS}

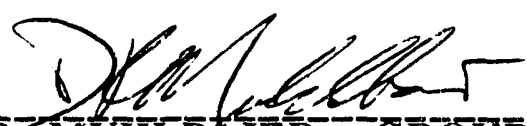

D.R. MUTLEAIER, GROUP' MĀNAGE'

Page 1 of 33. 


\section{Table of Contents}

Introduction

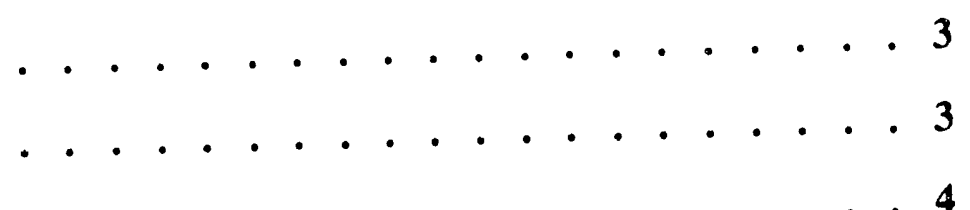

Experimental Apparatus

Non-prototypic Issues

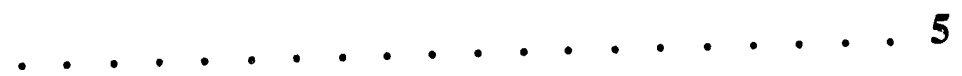

Collection of Data

Summary

Analysis of Data

Uncertainty Analysis

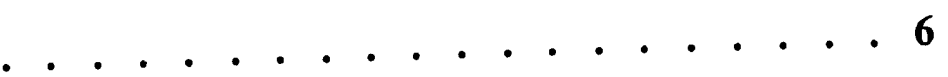

Conclusions
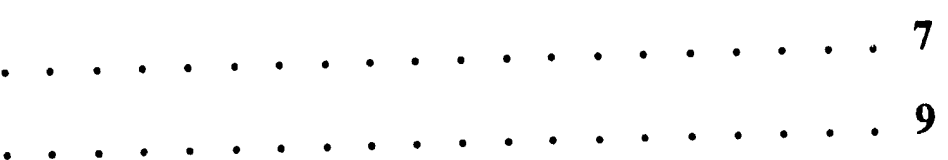

. . . . . . . . . . . . . . 11

References

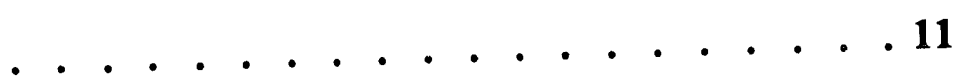

Nomenclature

List of Figures

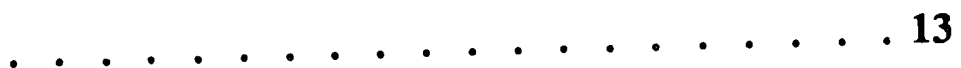

List of Tables

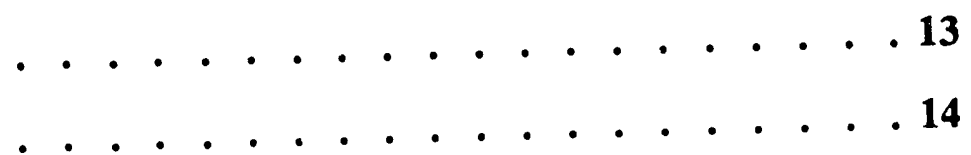

Figures

Tables 


\section{Introduction}

Following a hypothetical Loss of Coolant Accident (LOCA) the moderator level in the reactor tank would decrease. The current operating procedure with the new Type $Q$ Septifoil is to maintain Septifoil cooling during a LOCA. With the Type Q Septifoil the coolant flows up the Septifoil to ports above and just below the Poison Plate where it is discharged into the reactor tank. The coolant would then spray from the top of the Septifoil, splashing onto the Universal Sleeve Housings (USH) which house the assemblies, and enhance the cooling of the assemblies. The goal of the experiments performed in the HTL under Task Plan 92-062-1 was to determine the flow rate down the outside of the USH as a function of Septifoil flow. Information on USH cooling is necessary in the calculation of Gamma Heating Power Limits for K Reactor. This task (92062-1) parallels a similar task (90-074-1) which was performed to redesign the Septifoil (Type Q) and verify its performance. The facility that was used was the same test facility as that used by the previous task, namely Poison Plate Flow Test Rig [1].

\section{Summary}

A relationship between the flow rate inside a Septifoil to the water collected by an USH is presented. Of primary concern was the behavior at low flow rates. The graphical presentation of the data will be supported with videotape and observations, by the Test Engineer, of the flow phenomenon. The videotape is titled "Poison Plate" (HTLV-92-01M) and is stored in the HTL Video Files. The test apparatus consisted of three Septifoils, each with six USHs surrounding it. This geometry is prototypic of the reactor and can be seen in drawing ST-MDX5-10087. The non-prototypic aspects of the experiment, geometric and otherwise, will be discussed later in this report. Three groups of data were collected depending on whether the apparatus was vertical, tilted 0.5 " per 48 " East, and tilted $0.5^{\prime \prime}$ per $48^{\prime \prime}$ West. Supplemental testing was performed after preliminary investigation of the early results showed a drop in the USH collection flow rate near a Septifoil flow rate of about 7 GPM. The supplemental data supported the earlier data at low flow rates ( $<10$ GPM) and expanded the range of data to 20 GPM by resolving nonprototypic issues. 


\section{Experimental Apparatus}

A schematic diagram of the test apparatus is shown in Fig. 1. The HTL process water supply is divided into three branches, one for each Septifoil. Water flowing through each branch passes through a pressure regulator, one or two rotameters, and then to the bottom of the Septifoil. The water spraying out the top of the Septifoil hits and runs down the surrounding USHs. Three of these USHs are designated as "Collectors". The Collectors trap the water running down them and channel it into a bucket to be weighed. Timing how long it took to get a certain weight yields the flow rate of water hitting that USH.

Initially, it was assumed that one USH Collector could receive spray from more than one Septifoil and the location of the Collectors was chosen to account for that fact. Refer to drawings ST-MDX5-10087, ST-MDX5-10088, and ST-MDX5-10089 for details. In addition to these drawings a top view of the test apparatus is given in Fig. 2 showing the location designation of each Septifoil and collector. The nomenclature of Fig. 2 will be consistent with that used to present the results in graphs Figs. 3, 7, 8, and 9. Figure 2 also shows the apparatus orientation with respect to North, South, East, and West. Technical Procedure TP-92-026, Test Procedure for USH Cooling Via Septifoil: Reduced Flow [2], has a copy of Fig. 2 on Page 5 with the original designations labeled by the Test Engineer. The original copy of Fig. 2 can be found in TP-91-019 [3].

After preliminary investigation of the results obtained from Test Procedure TP-92-026 it was decided that a closer investigation was required. Supplemental data was taken using Test Procedure TP-92-030. A schematic diagram of the test apparatus used under this procedure is given in Fig. 3. The changes made to the test section, shown in Fig. 3, for the supplemental data will be discussed next. A full-sized USH was used in place of the USH collectors made for this rig. The USH used was chosen because it had an oxidized surface for the proper wetting characteristics and it could protrude below the Poison Plate farther than the USH collectors. The ISH was suspended by a hoist such that about 8 feet of the USH hung below the Poison Plate. One USH was used to collect water from only one Septifoil. It was observed that, due to the hole alignment, the second Septifoil did not add any water to the USH collector. Every hole in a Septifoil is pointing at one of its neighboring USHs. After running one set of data for Septifoil flow rates from 2 to 8 GPM the Septifoil support plate was removed and the lower section of the support plate that protruded below the tank bottom was removed (refer to drawing ST-MDX5-10087). The 
reason for removing this protrusion will be discussed in the Non-prototypic Issues section of this report. A second set of supplemental data was taken for a Septifoil flow rate range of 6 to $20 \mathrm{GPM}$.

\section{Non-prototypic Issues}

There are four issues discussed where the test rig is non-prototypic with respect to the $\mathrm{K}$ Reactor. The first two issues were not of primary concern to this task and will be discussed first. The third issue was of primary concern and it deals with the flow rate to the Septifoil. The fourth issue relates to the Septifoil holes above the Poison Plate and was only of concern at high Septifoil flow rates.

The first two issues relate to the fact that this task was an unheated experiment that used building water. In the actual event of a LOCA the reactor components would generate heat and the fluid pumped through the Septifoils would be a mixture of $\mathrm{D}_{2} \mathrm{O}$ and $\mathrm{H}_{2} \mathrm{O}$. The amount of fluid from the Septifoil that hits and clings to the USH is dependent upon the fluid surface tension and density. Since $\mathrm{D}_{2} \mathrm{O}$ and $\mathrm{H}_{2} \mathrm{O}$ have similar fluid properties the use of $\mathrm{H}_{2} \mathrm{O}$ does not jeopardize the validity of the data. The maximum USH temperatures expected in the event of a LOCA are in the neighborhood of $40^{\circ} \mathrm{C}$ [4]. The evaporation rate for a $40^{\circ} \mathrm{C} \mathrm{USH}$ is not significantly higher than the evaporation rate for the $21^{\circ} \mathrm{C} \mathrm{USH}$ of this experiment, thereby justifying the use of an unheated USH.

The flow rate to the Seprifoil is measured in the reactor and the actual flow rate within the Septifoil is some value less than the measured value because of losses at the Septifoil base. There is a gap between the Septifoil mounting pin, on the tank bottom, and the Septifoil where a small amount of the measured flow rate is lost. In the test apparatus for this experiment the measured flow rate is actually the flow rate within the Septifoil itself. It is important to note that the flow rate reported in the figures of this report represent the flow rate within the Septifoil itself and are not modified to incorporate the gap losses. Hart and Steimke [5] measured the gap loss to be $1.0 \pm 0.25$ GPM.

The fourth issue that is non-prototypic with the $\mathrm{K}$ Reactor relates to the flow exiting the Septifoil out the upper slots. In the test apparatus there are Septifoil Support Plates that protrude below the tank top. This part can be seen best in drawing ST-MDX5-10087 as 
part number 30. It can also be seen in drawing ST-MDX5-10089M. At moderate Septifoil flow rates ( 7 - 20 GPM) water flowing out the slots above the Poison Plate may strike the Support Plate and be diverted in some manner. It is reported in the laboratory notebook (WSRC-NB-92-205) on page 13 that at a Septifoil flow rate of about 7 GPM the flow from the slots above the Poison Plate starts to disturb the flow rate out the holes below the Poison Plate. Septifoil flow rates needed to cause water to splash onto the protrusion of the Septifoil Support Plate would need to be somewhat greater than 7 GPM. All the data taken above 7 GPM, from the first test procedure (TP-O2-026), is of no value due to this non-prototypic issue. The data taken above 7 CFM, from procedure TP-92-026, does not appear in any of the figures but can be seen in Table I, II, and III. The supplemental data taken with the second test procedure (TP-92-030) accounted for this non-prototypic issue by removing the protrusion of the Septifoil Support Plate below the tank bottom. The removal of the protrusion made the test rig prototypic with respect to the K-Reactor according to drawing W133485.

\section{Collection of Data}

The data was recorded manually and was written into laboratory notebook WSRC-NB-92205. The first set of data was recorded in accordance with NRTSC Technical Procedure TP-92-026 'Test procedure for USH Cooling Via Septifoil; Reduced Flow' on data sheets given in the procedure. The supplemental data was recorded in accordance with NRTSC Technical Procedure TP-92-030 'Supplemental Testing for USH Cooling Via Septifoil' on data sheets given in the procedure. The data is reproduced in spreadsheet format in Table I thru Table IV. The data recorded were the flow rate to each Septifoil, the weight, time, and temperature of water running down each collector (USH), and the tilt status of the apparatus. The weight, time, and temperature of water running down each collector were used to obtain the collector flow rates in GPM. The density relationship used to convert the weight of water collected into a volume of water was derived from data given in LANGE'S HANDBOOK OF CHEMISTRY, Ref. [6]. The density versus temperature relationship is given below.

$$
\begin{gathered}
\rho=62.4401+2.304 \mathrm{E}-4(\mathrm{~T})-3.508 \mathrm{E}-4\left(\mathrm{~T}^{2}\right)+8.796 \mathrm{E}-7\left(\mathrm{~T}^{3}\right) \\
\text { Where; } \quad \rho \text { has units of } \mathrm{Lb} \mathrm{m}_{\mathrm{m}} / \mathrm{ft}^{3} . \\
\text { T has units of }{ }^{\circ} \mathrm{C} .
\end{gathered}
$$


The percent of the circumference wetted at a distance of 4 feet below the Poison Plate was also recorded as part of the supplemental data. The distance from the Poison Plate where the total circumference was wetted was also recorded as part of the supplemental data. A distance of greater than 8 feet for total circumferential wetting could not be recorded because the USH did not extend more than 8 feet below the Poison Plate.

\section{Analysis of Data}

The data is presented graphically, to relate the flow rate from the Septifoil to the flow rate down the USH sleeve collectors, in Fig. 4. This graph represents the data from the 'no tilt' case. Figure 4 does not present the full range of data acquired but does present the range of data of primary concern to this study. The Septifoil flow rates range from 0 to $10 \mathrm{GPM}$ and the USH sleeve collector flow rates range from 0 to $1.6 \mathrm{GPM}$. There are three sets of data represented in Fig. 4. The same data are plotted two different ways in Fig. 4. The first three symbols show the USH flows for the average of the three Septifoil flows. The second three symbols show the same USH flows for the flow from the nearest Septifoil. The results are the same for these two sets of data. The third set of data represents the data collected in the supplemental testing (shown as $\mathrm{C}^{*}$ ). The three sets of data are virtually superimposed which reveals that there was very little deviation in the individual Septifoil flow rates and that the supplemental data supported the previous data findings. Error bars are shown, in Fig. 4, for characteristic USH collector flow rates and for the Septifoil flow rates (Rotameters).

Figure 4 shows that USH flow generally increases with increasing Septifoil flow. However, there in a relative minimum in the USH sleeve collector flow rates at a Septifoil flow rate of approximately $7 \mathrm{GPM}$. It was mentioned earlier in this report that the laboratory notebook (WSRC-NB-92-205) records visual observation of the phenomenon occurring at that particular Septifoil flow rate. At a Septifoil flow rate of about 5 GPM water starts to flow out the slotted holes of the Septifoil above the Poison Plate. The water flowing out the slots clings to the Septifoil and disturbs the water flowing out the holes below the Poison Plate. Photographs are presented in Figs. 5 thru 7 to support this observation. These photographs were taken from the videotape and show the discharge water from the top of the Septifoil. In Fig. 5 the Septifoil flow rate is 4 GPM and there is no water flowing out the slots above the Poison Plate to disturb the water flowing ot:t the 
holes below the Poison Plate. At a Septifoil flow rate of 5 GPM (Fig. 6) water has started to flow out the slots and disturbs the flow of water out the holes. The actual water flowing out the slots is not clearly visible, in Fig. 6, but the flow of water out the holes is disrupted by a stream of water exiting the slots that clings to the Septifoil. In Fig. 7 the Septifoil flow rate is 7 GPM and the water flowing out the slots is clearly visible. What yields the low USH collector flow rates at the Septifoil flow rate of 7 GPM can be seen by comparing Fig. 6 with Fig. 7. In Fig. 7 the water flowing out the slots is strong enough to cause the water flowing out the holes to cling to the Septifoil, which is not the case in Fig. 6.

Figure 8 represents the data of Fig. 4 along with the supplemental data for flow rates up to 20 GPM. The symbol convention for Fig. 8 is the same as for F.g. 4. The data collected after removing the protrusion of the Septifoil support sleeve, to make it prototypic, is represented by the USH collector symbol C**. Figure 8 shows that for Septifoil flow rates above 7 GPM the USH collector flow rates increase with increasing Septifoil flow. Error bars are shown, in Fig. 8, for characteristic USH collector flow rates and for the Septifoil flow rates (Rotameters).

In order to determine how well a given USH Sleeve Collector flow rate wets the USH Sleeve, the percent of the circumference wetted at a distance of 4 feet below the Poison Plate and the distance below the Poison Plate at which the entire circumference was wetted is plotted in Fig. 9. The criterion for determining if a surface was wetted was that a stick of wood showed a meniscus when pulled away from the USH surface. The information shown in Fig. 9 is from the supplemental tests only. Figure 9 shows that an USH Sleeve Collector flow rate of 0.5 GPM fully wets the USH at a distance of about 8 feet below the Poison Plate. Referring back to Figs. 4 and 8 it can be shown that the USH sleeve Collector flow rate of 0.5 GPM corresponds to a Septifoil flow rate of about 3 or 7 GPM.

For USH Sleeve Collector flow rates between about 1.5 GPM and 3.0 GPM, in Fig. 9, the distance below the Poison Plate where the circumference is fully wetted is between one and two feet. It can be shown in Fig. 8 that USH Sleeve Collector flow rates of 1.5 to 3.0 GPM correspond to Septifoil flow rates of about 10 to 22 GPM, respectively. Therefore, increasing the Septifoil flow rate from 10 to 22 GPM does not significantly shorten the distance below the Poison Plate at which the USH is fully wetted. It is important to note, again, that this Septifoil flow rate is the amount of water exiting the top of the Septifoil. 
Figure 10 demonstrates the effect that tilting the apparatus has on the amount of water collected by the USH. Figure 10 presents three graphs that represent the data from USH collector C1, collector C2, and collector C3. For all three graphs the Septifoil flow rate is given as the flow rate of the Septifoil closest to the respective USH (refer to Fig. 2). There are no consistent differences between the data for No Tilt, Tilt West, and Tilt East. Therefore it is concluded that a tilt of 0.5 " per 48 " has no statistically significant effect on the amount of water received by an USH. Error bars are not shown in Fig. 10 but the uncertainties are identical to those of Figs. 4 and 8.

\section{Uncertainty Analysis}

Uncertainties are marked on the figures. The uncertainty analysis for the data taken with procedure TP-92-026 will be discussed first. The data taken with procedure TP-92-030 (the supplemental data) has a lower uncertainty and will be discussed later.

The uncertainty of the independent variable (Septifoil flow rate) will be presented first. From the M\&TE files and post-test calibrations of the four rotameters used in this experiment the uncertainty of the Septifoil flow rate can be determined. The worst case uncertainty, for the data taken with procedure TP-92-026, was for the 0 - 50 GPM Rotameter (TR-148). A graphical presentation of both the Bias and Precision errors along with the Root-Sum-Squares of the two errors for all the Rotameters used in this experiment is given in Figs. 11 and 12. The Bias uncertainty is evaluated as the difference between the Pre- and Post-Test calibrations. The relatively large Bias is the result of the calibrating technician reading the float at different points. From Fig. 11 it is shown that the worst uncertainty of the Septifoil flow rates is within \pm 1.2 GPM. The remaining three rotameters used in this experiment have uncertainties within \pm 0.6 GPM according to Figs. 11 and 12. The evaluation of all uncertainties for this report is in accordance with Uncertainty and Calibration Analysis (U), by D.A. Coutts [7].

The uncertainty of the dependent variable (collector flow rate) is somewhat more involved and will be presented next. The flow rate $(Q)$ is a function of the measured weight, the density, and the time to collect that weight of water.

$$
Q=\frac{W}{\rho t}
$$


The uncertainty of the flow rate, as prescribea in Ref. [6], is given as follows.

$$
\omega_{\mathrm{Q}}=\sqrt{\Sigma\left(\frac{\partial \mathrm{Q}_{\mathrm{X}}}{\partial \mathrm{X}_{\mathrm{i}}} \omega_{i}\right)^{2}}
$$

For the previous flow rate relationship, this equation is written as follows.

$$
\omega_{Q}=\sqrt{\left(\frac{Q}{W} \omega_{W}\right)^{2}+\left(\frac{-Q}{\rho} \omega_{\rho}\right)^{2}+\left(\frac{-Q}{t} \omega_{t}\right)^{2}}
$$

The density in these calculations is actually a function of temperature and the relationship was derived from a table of values. For this situation the density uncertainty $\left(\omega_{\rho}\right)$ is given by the following expression.

$$
\omega_{\rho}=\sqrt{\left(\omega_{\rho, e q}\right)^{2}+\left(\frac{\partial \rho}{\partial T} \omega_{T}\right)^{2}}
$$

The following table shows the values used to determine the USH collector flow rate uncertainty. These values were obtained from the M\&TE files on the instruments used to perform this experiment.

\begin{tabular}{|c|c|}
\hline$\omega_{\rho, \text { eq }}$ & $\pm 0.00307 \mathrm{Lb} / \mathrm{cuft}$ \\
\hline$\omega_{\mathrm{W}}$ & $\pm 0.61 \mathrm{Lb}$ \\
\hline$\omega_{\mathrm{T}}$ & $\pm 1^{\circ} \mathrm{C}$ \\
\hline$\omega_{\mathrm{t}}$ & $\pm 0.2 \mathrm{sec}$ \\
\hline
\end{tabular}

Tables V, VI, and VII are spread sheets demonstrating the analysis of the USH collector flow rate uncertainty for the No-Tilt, East-Tilt, and West-Tilt cases, respectively. Table VIII shows the spread sheet analysis for the Supplemental data USH collector flow rate uncertainty. Using Tables V, VI, VII, and VIII the USH collector flow rate uncertainty can be expressed as a function of the USH collector flow rate. All the USH collector flow rate uncertainties fall within the range of the following equation.

$$
\omega_{\text {collector }}= \pm\left[0.05+0.2^{*}(\text { collector GPM })\right]
$$

This equation is represented by the error bars in Figs. 4, 10, and 11 .

The uncertivinty analysis for the supplemental data follows the same process as the previous analysis. Two 0-11 GPM rotameters were used to measure the Septifoil flow rate for the supplemental data. The uncertainty of the independent variable (Septifoil flow rate) was reduced from $\pm 1.2 \mathrm{GPM}$ to $\pm 0.32 \mathrm{GPM}$ by using two rotameters with smaller ranges. A graphical presentation of both the Bias and Precision errors along with the Root-SumSquares of the two errors is given in Fig. 12 for both rotameters (TR-124 \& TR-125). Figure 12 also illustrates the total uncertainty as the Root-Sum-of-Squares of the two 
rotameters pre- and post-test uncertainties. The uncertainty of the dependent variable (USH Collector flow rate) is evaluated identically as before. The resi's of these calculations are presented in spreadsheet format in Table VIII. Similar to the previous data, the USH collector uncertainty can be represented by the previous equation relating USH collector uncertainty to the USH collector flow rate.

\section{Conclusion}

The main purpose of this task was to establish a minimum Septifoil flow rate that would maintain USH cooling via the Septifoil during a LOCA. It has been shown that a Septifoil flow rate of $3 \mathrm{GPM}$ provides an USH Collector flow rate of $0.5 \mathrm{GPM}$ and wets the entire circumference of the USH at a distance of about 8 feet below the Poison Plate. It was observed that a Septifoil flow rate of about 7 GPM may yield an USH Collector flow rate below 0.5 GPM and may require more than 8 feet of USH before the entire circumference of the USH is wetted. A Septifoil flow rate of $10 \mathrm{GPM}$ yields an USH Sleeve Collector flow rate of $1.5 \mathrm{GPM}$ and wets the entire circumference of the USH at a distance just over 1 foot below the Poison Plate. As the Septifoil flow rate increases above 10 GPM the USH Sleeve Collector flow rate increases proportionally; however, there was no noticeable advantage in the wetting of the USH other than a thicker fluid layer caused by the increased flow rate.

\section{References}

[1] J.L. Steimke, "Design and Testing of Septifoil Modification", Task Number 90074-1, Rev. 2, June 1991.

[2] T.L. Spatz, "Test Procedure for USH Cooling Via Septifoil; Reduced Flow", Technical Procedure TP-92-026, June 1992.

[3] M.D. Fowley and J.L. Steimke, "Testing Poison Plate Rig", Technical Procedure TP-91-019, June 1991.

[4] A.L. Kielpinski, "Extesion of Constant USH Temperature Analysis to Lower Septifoil Flow", NES-CDG-920105, June 8, 1992.

[5] C.M. Hart and J.L. Steimke, "Measurements of Water Trajectory in LTFF", NESETH-920202, Rev. 1, June 5, 1992. 
[6] John A. Dean, LANGE'S HANDBOOK OF CHEMISTRY 13th Ed., McGrawHill Book Co., New York, NY, 1985, pp. 10-91.

[7] D.A. Coutts, "Uncertainty and Calibration Analysis (U)", WSRC-TR-91-106, March 1991.

\section{Nomenclature}

$\begin{array}{ll}\text { C1 } & \text { USH sleeve collector. } \\ \text { C2 } & \text { USH sleeve collector. } \\ \text { C3 } & \text { USH sleeve collector. } \\ C^{*} & \text { USH for supplemental data. } \\ C^{* *} & \text { USH for supplemental data, expanded flow range. } \\ \text { Q } & \text { Flow rate (GPM) } \\ \text { t } & \text { Time (min) } \\ \text { T } & \text { Temperature }\left({ }^{\circ} \mathrm{C}\right) \\ \text { USH } & \text { Universal Sleeve Housing } \\ \text { W } & \text { Weight }(\text { Lbf }\end{array}$

\section{Greek Symbols}

$\rho$

Density (Lbm/cuft)

$\omega$ Uncertainty 


\section{List of Figures}

Figure 1 Schematic diagram of test apparatus.

Page 14

Figure 2 Top view of enclosure with orientation labeling.

Page 15

Figure 3 Schematic diagram of Supplemental data test apparatus.

Page 16

Figure 4 Flow to USH sleeve collectors (no tilt data).

Page 17

Figure 5 Photograph of Septifoil discharge at 4 GPM

Page 18

Figure 6 Photograph of Septifoil discharge at 5 GPM

Page 19

Figure 7

Photograph of Septifcil discharge at 7 GPM

Page 20

Figure 8 Flow to USH sleeve collectors; expanded flow rates

Page 21

Figure 9 USH Collector Wetting Information

Page 22

Figure 10 Effect of tilt on USH sleeve collectors.

Page 23

Figure 11 Uncertainty of Septifoil flow rates (TR-148 and TR-20276). Page 24

Figure 12 Uncertainty of Septifoil flow rates (TR-124 and TR-125). Page 25

\section{List of Tables}

Table I No tilt data with analysis

Page 26

Table II East tilt ( $0.5^{\prime \prime}$ per $\left.48^{\prime \prime}\right)$ data with analysis.

Page 27

Table III

West tilt ( $0.5^{\prime \prime}$ per 48 ") data with analysis

Page 28

Table IV Supplemental data with analysis

Page 29

Table V USH collector uncertainty analysis, No tilt

Page 30

Table VI

USH collector uncertainty analysis, East tilt

Page 31

Table VII USH collector uncertainty analysis, West tilt

Page 32

Table VIII Supplemental data collector $\left(C^{*}\right.$ and $\left.C^{* *}\right)$ uncertainty analysis

Page 33 


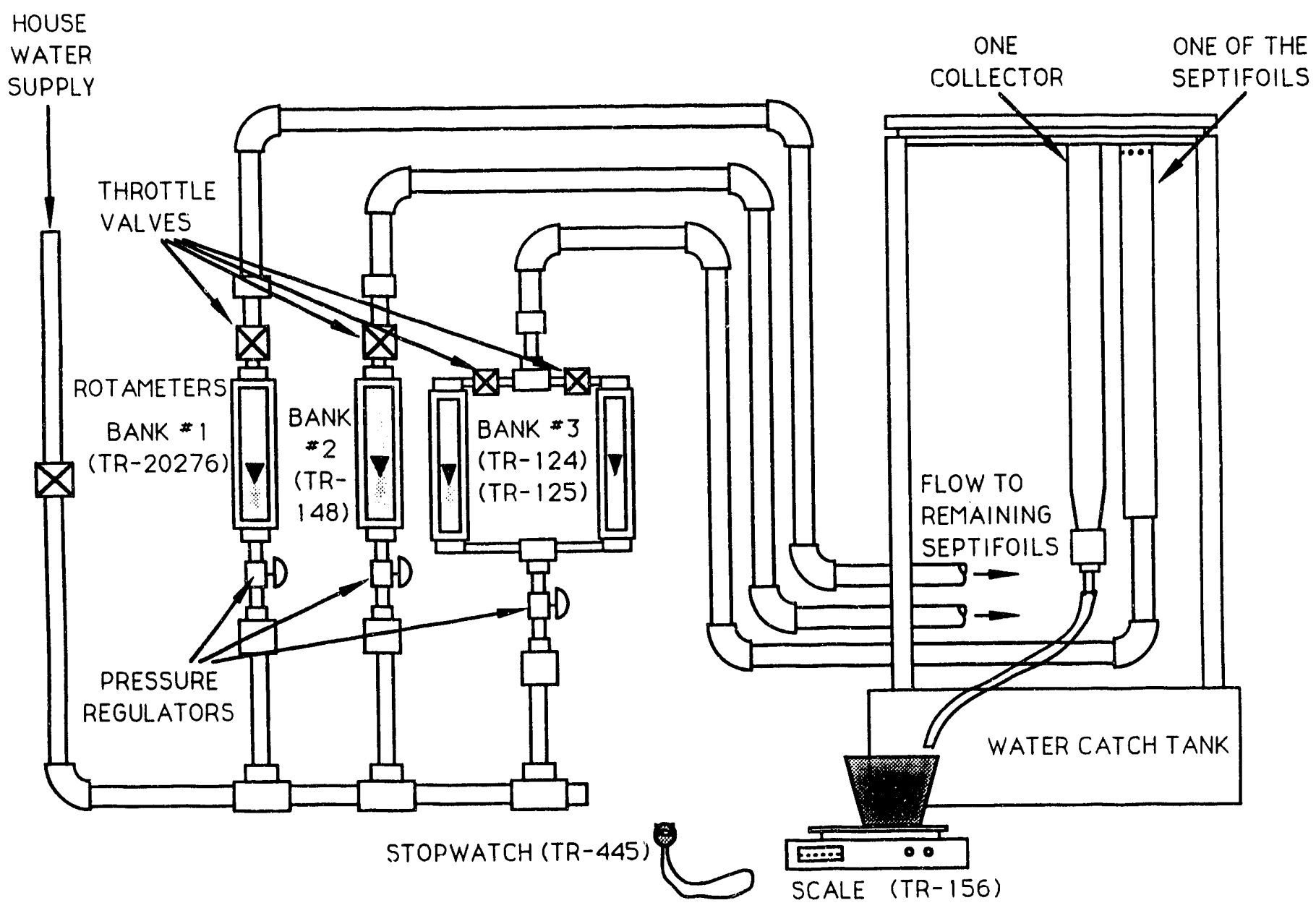

Figure 1: Schematic Diagram of Test Apparatus. 


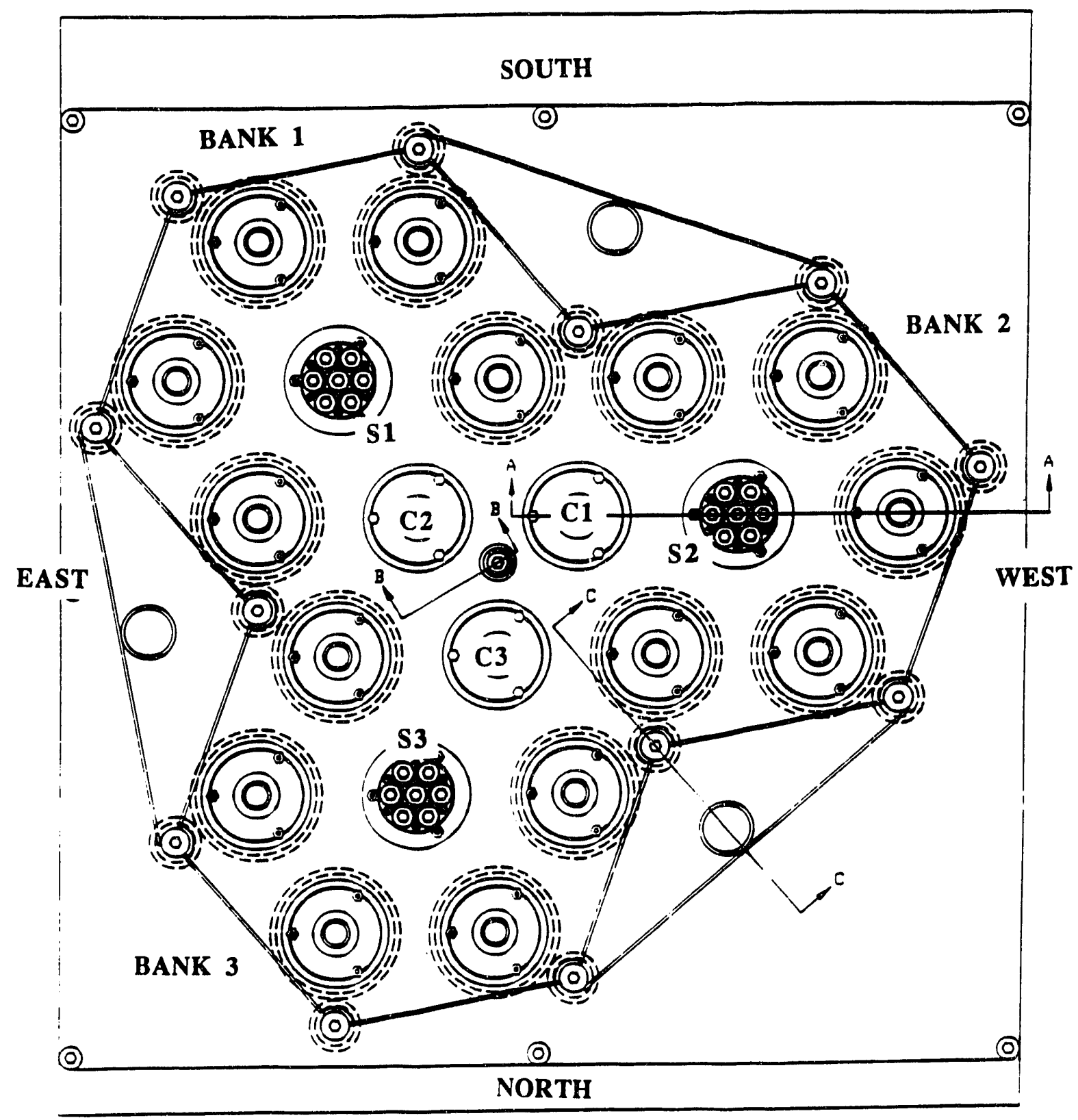

Figure 2: Top View of Enclosure With Orientation Labeling. 


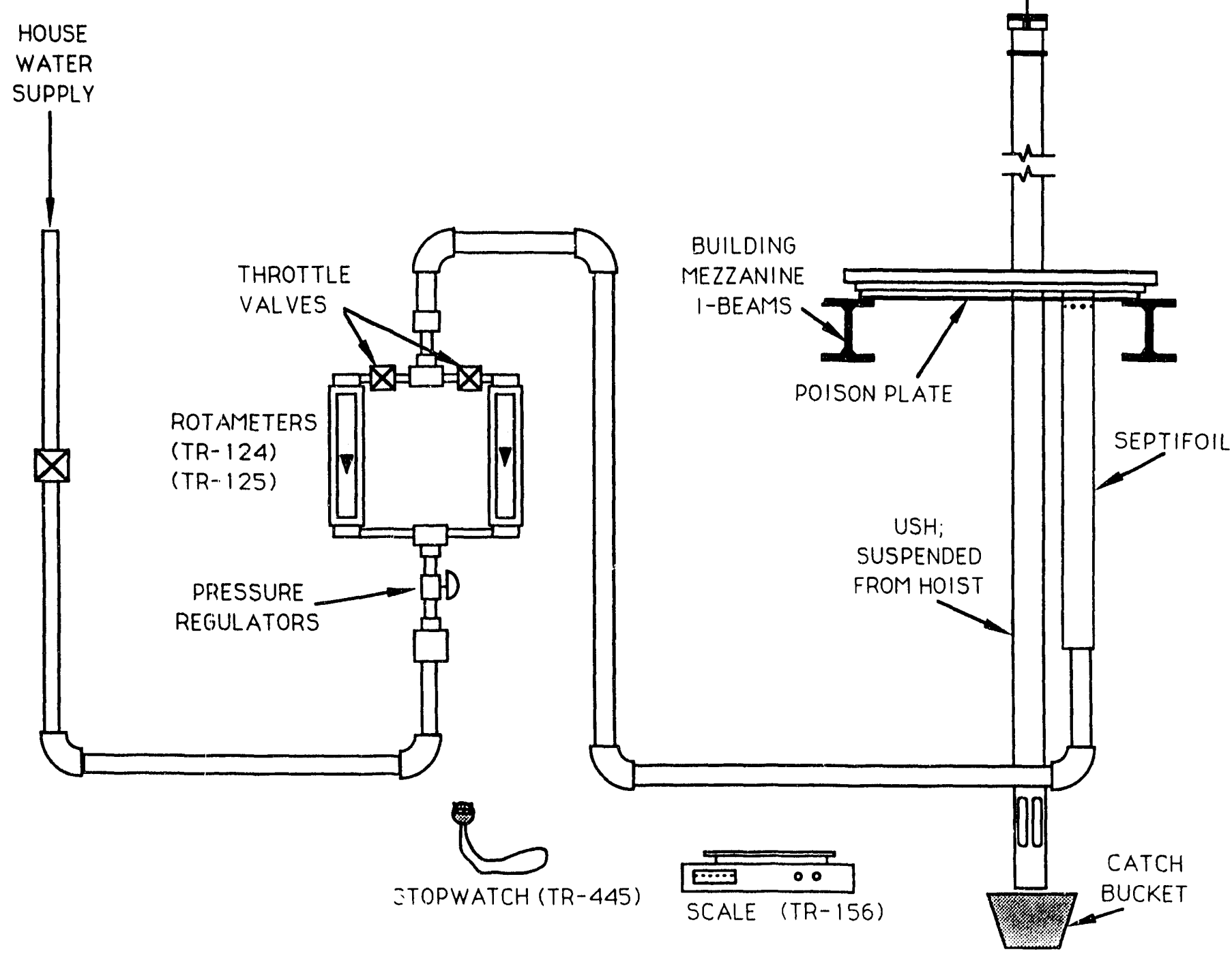

Figure 3: Schematic Diagram of Supplemental Data Test Apparatus. 
Flow to USH Sleeve Housing With No Tilt

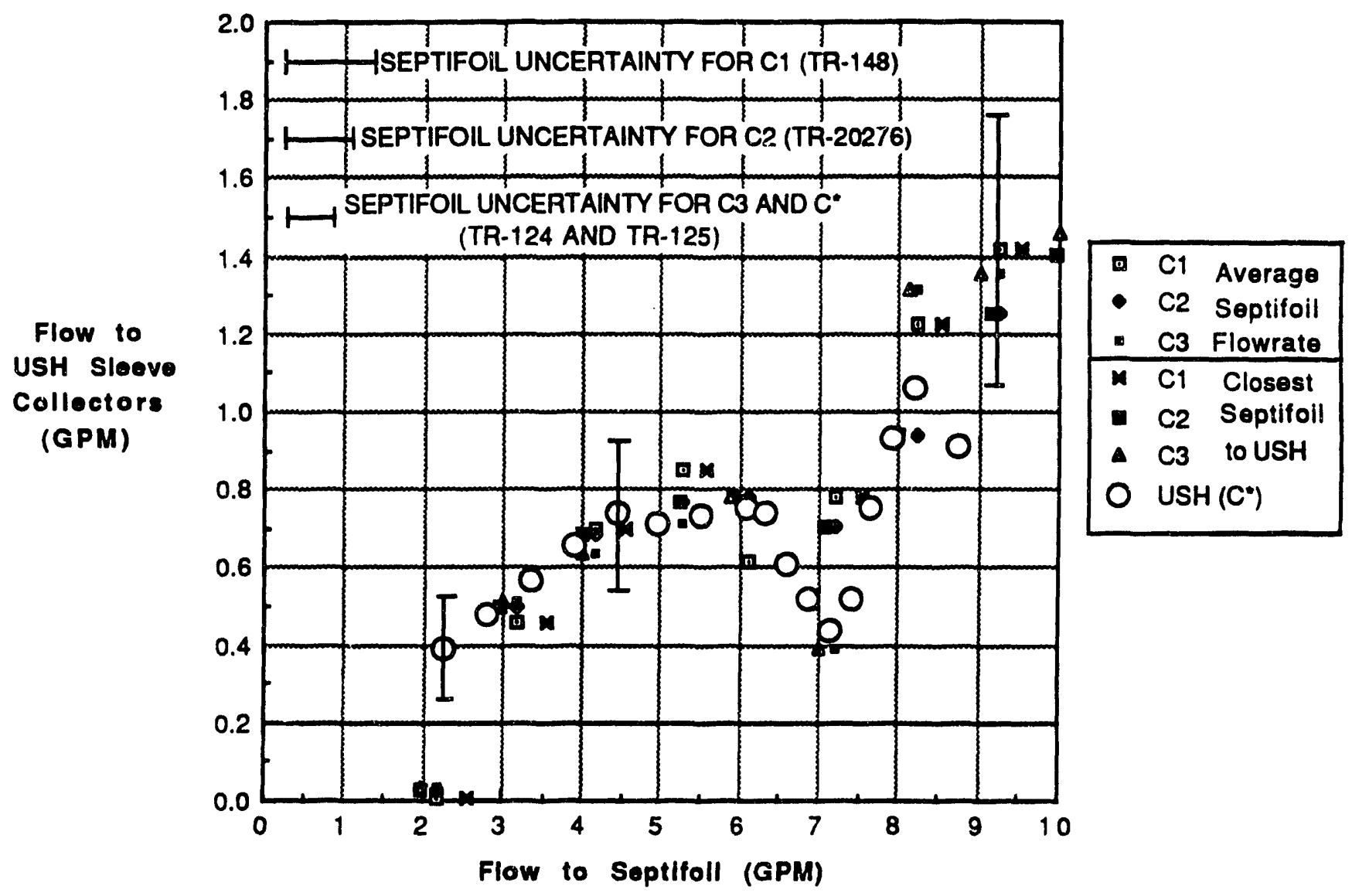

Figure 4: Flow to USH Sleeve Collectors (No Tilt Data). 


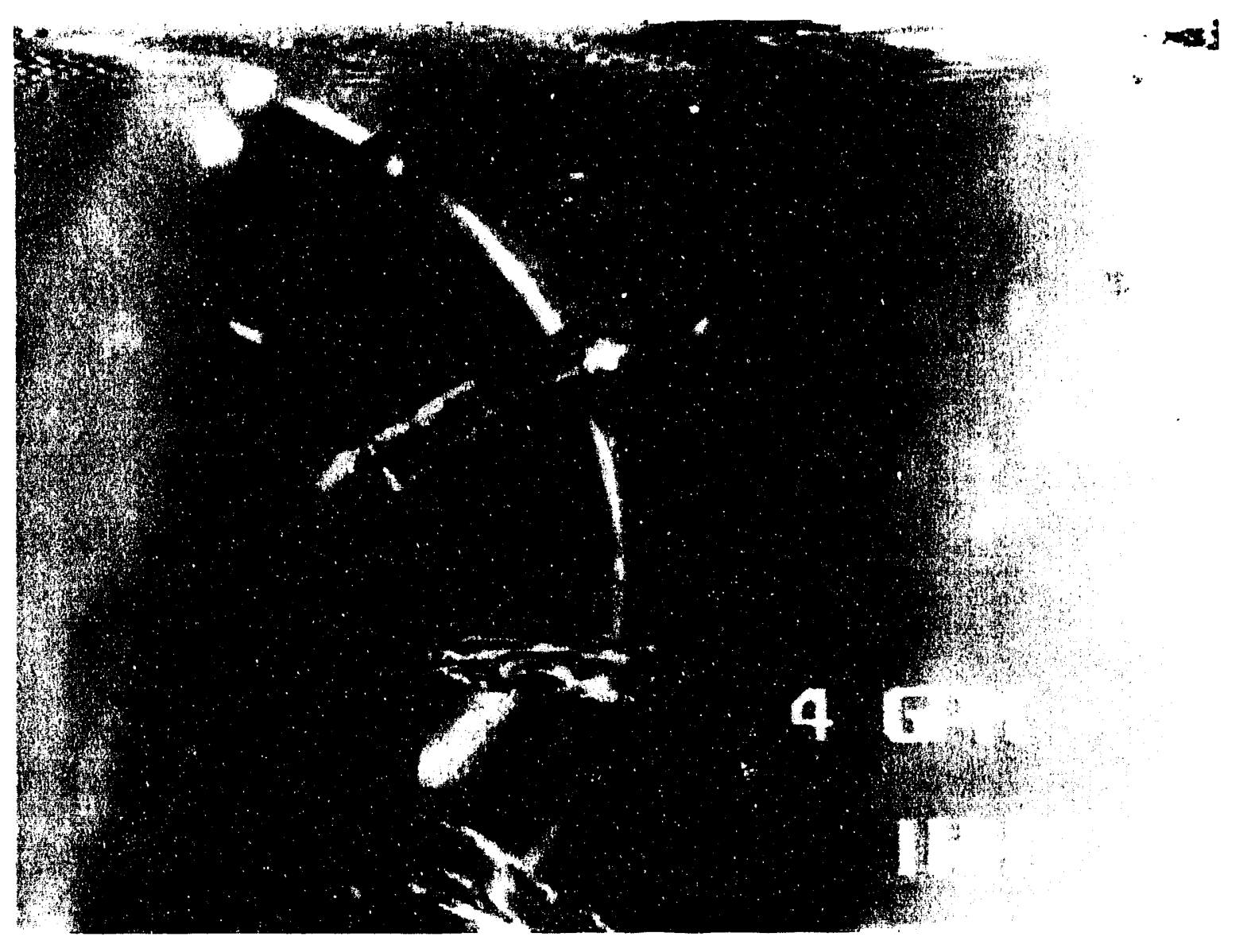

Figure 5: Photograph of Septifoil Discharge at 4 GPM. 


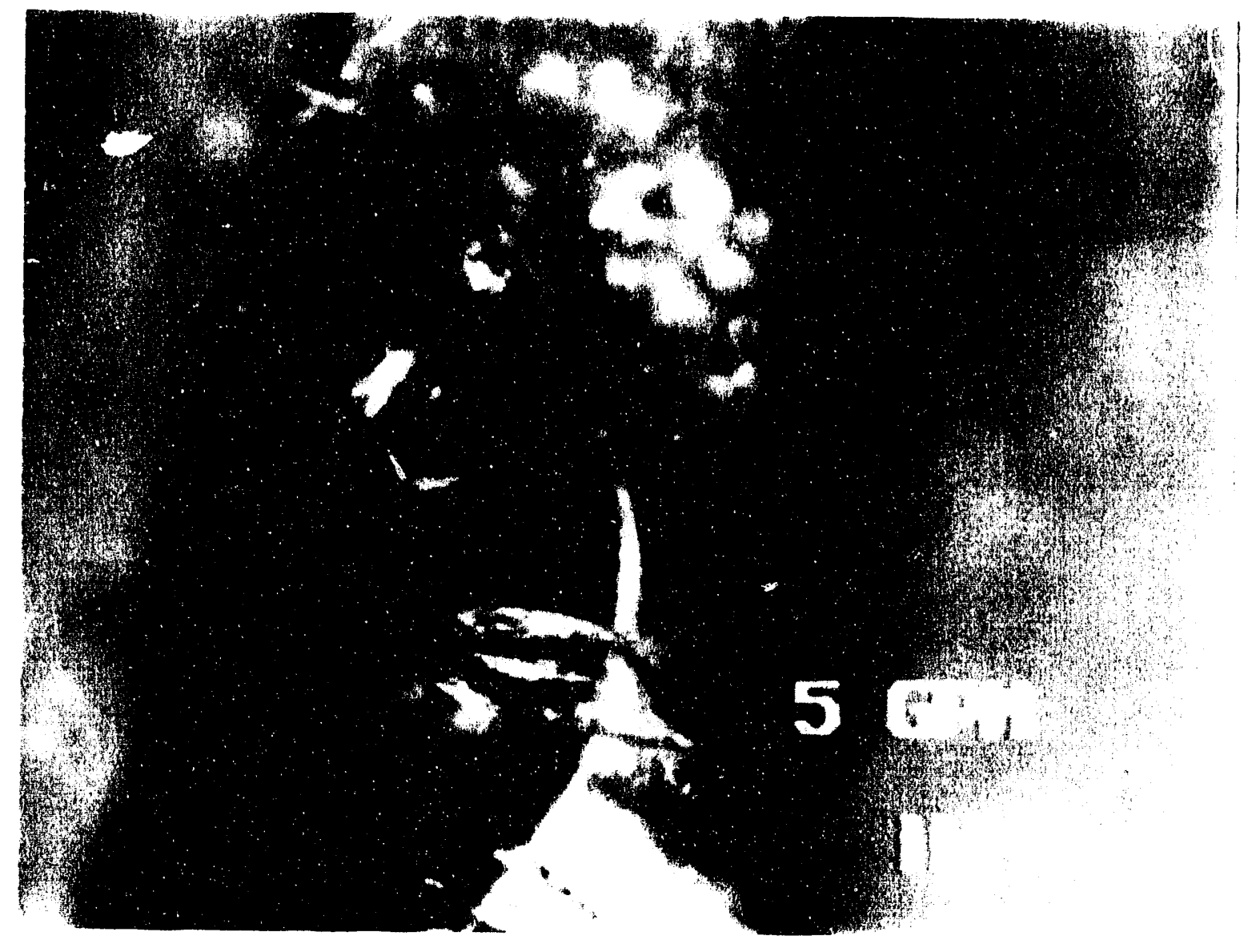

Figure 6: Photograph of Septifoil Discharge at 5 GPM. 


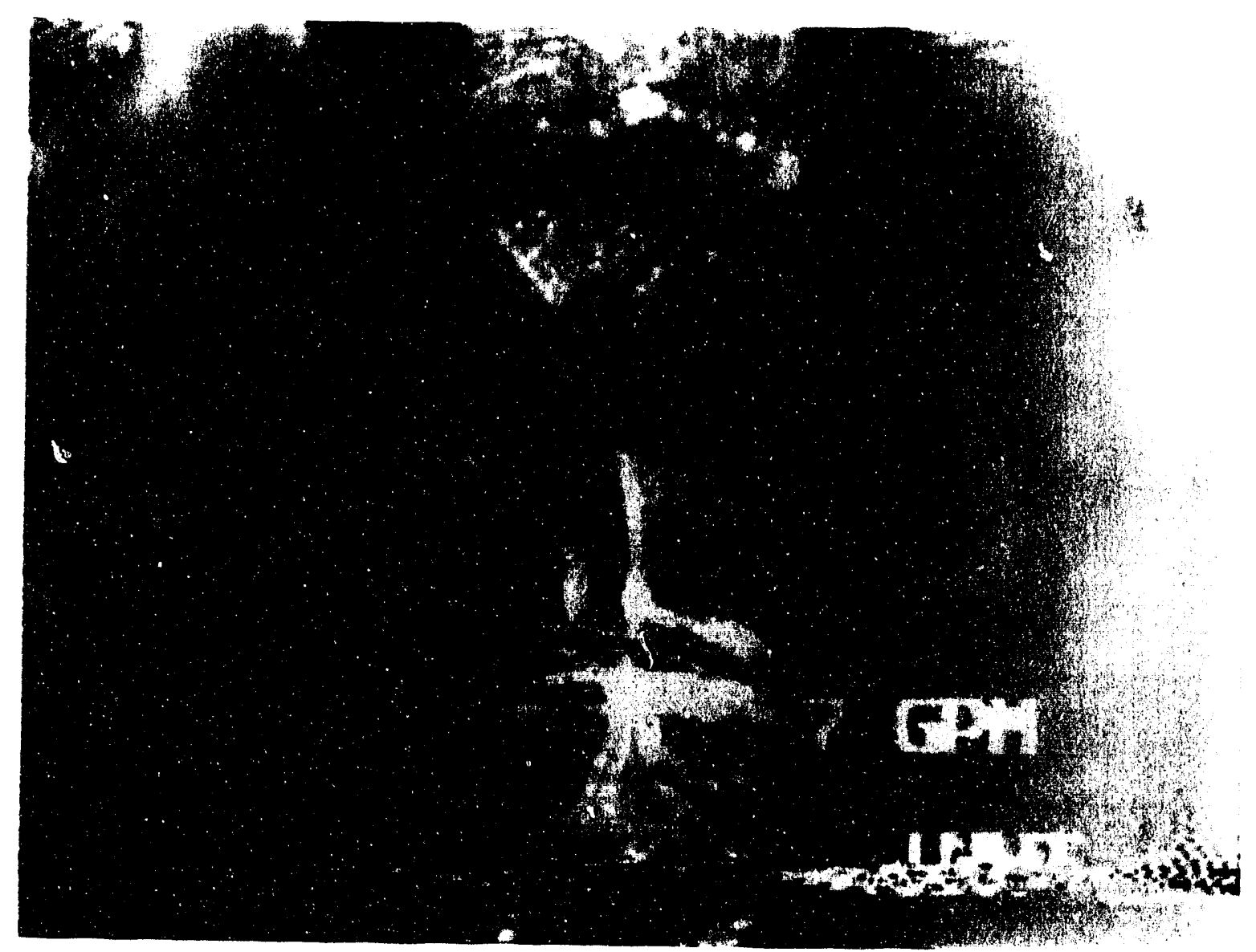

Figure 7: Photograph of Septifoil Discharge at 7 GPM. 
Flow to USH Sleeve Collectors; Expanded Flowrates

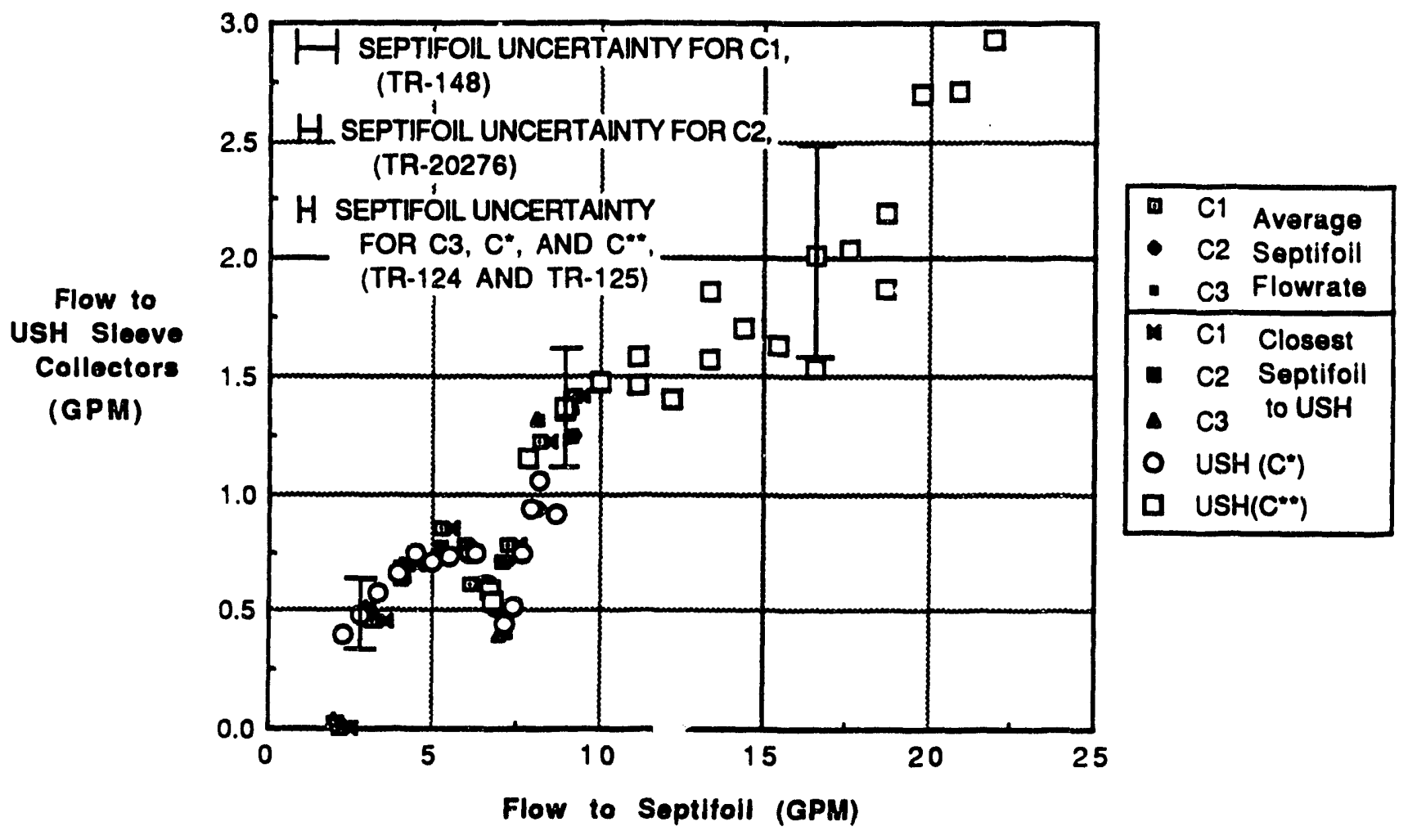

Figure 8: Flow to USH Sleeve Collectors; Expanded Flow rates. 
$\%$ of Circumference Wetted 4' Below Polson Plate

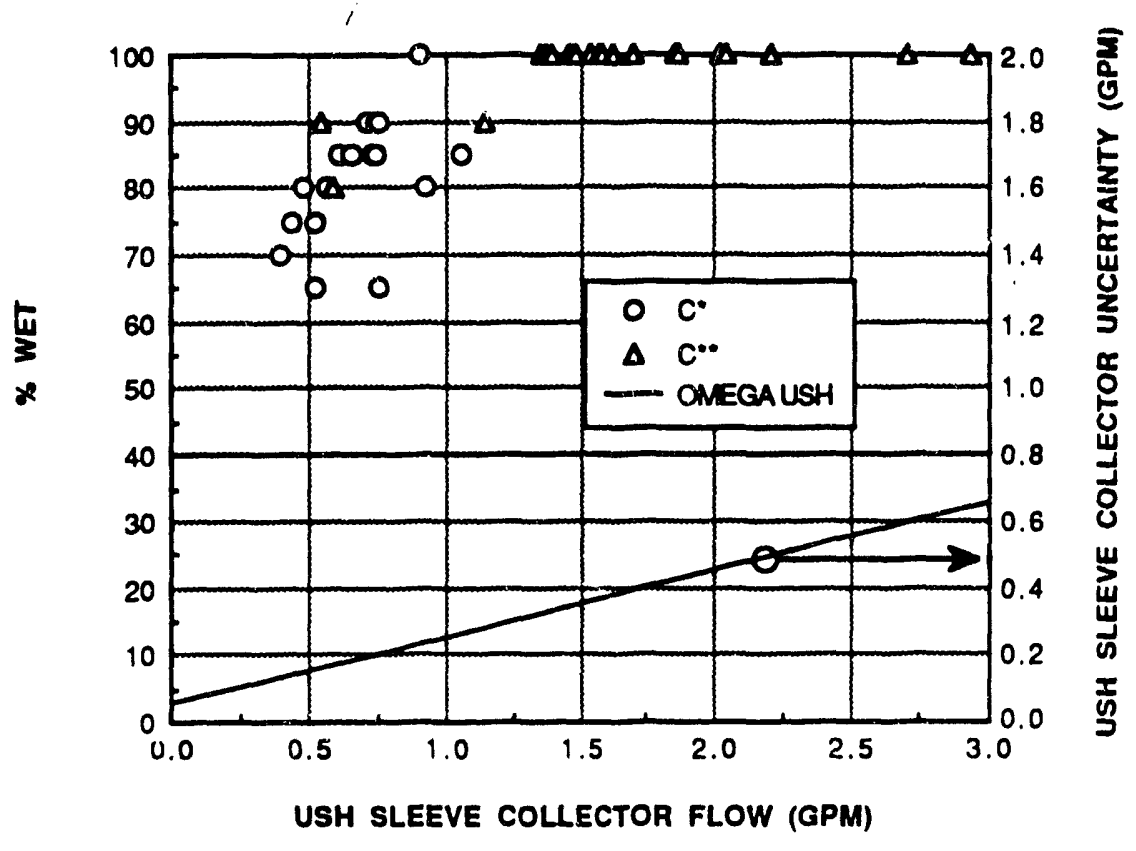

Distance From Poison Plate Where Circumference is Fully Wetted

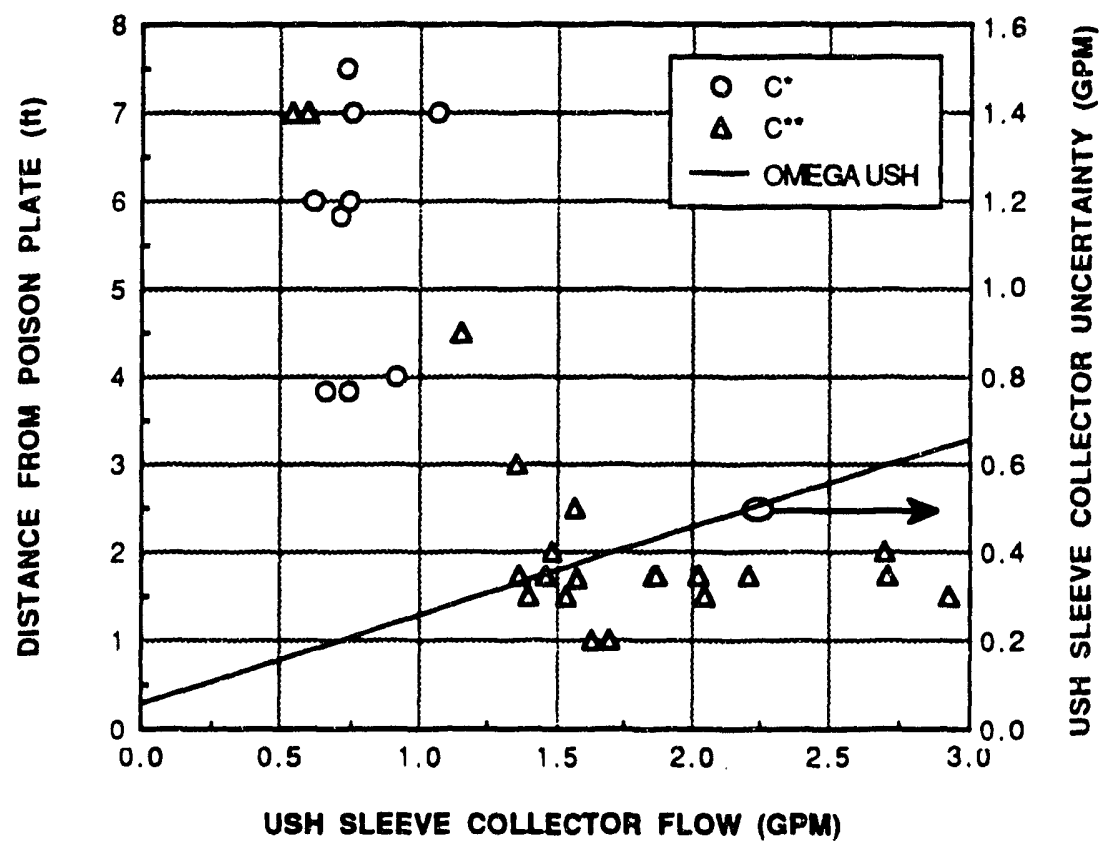

Figure 9: USH Collector Wetting Information. 

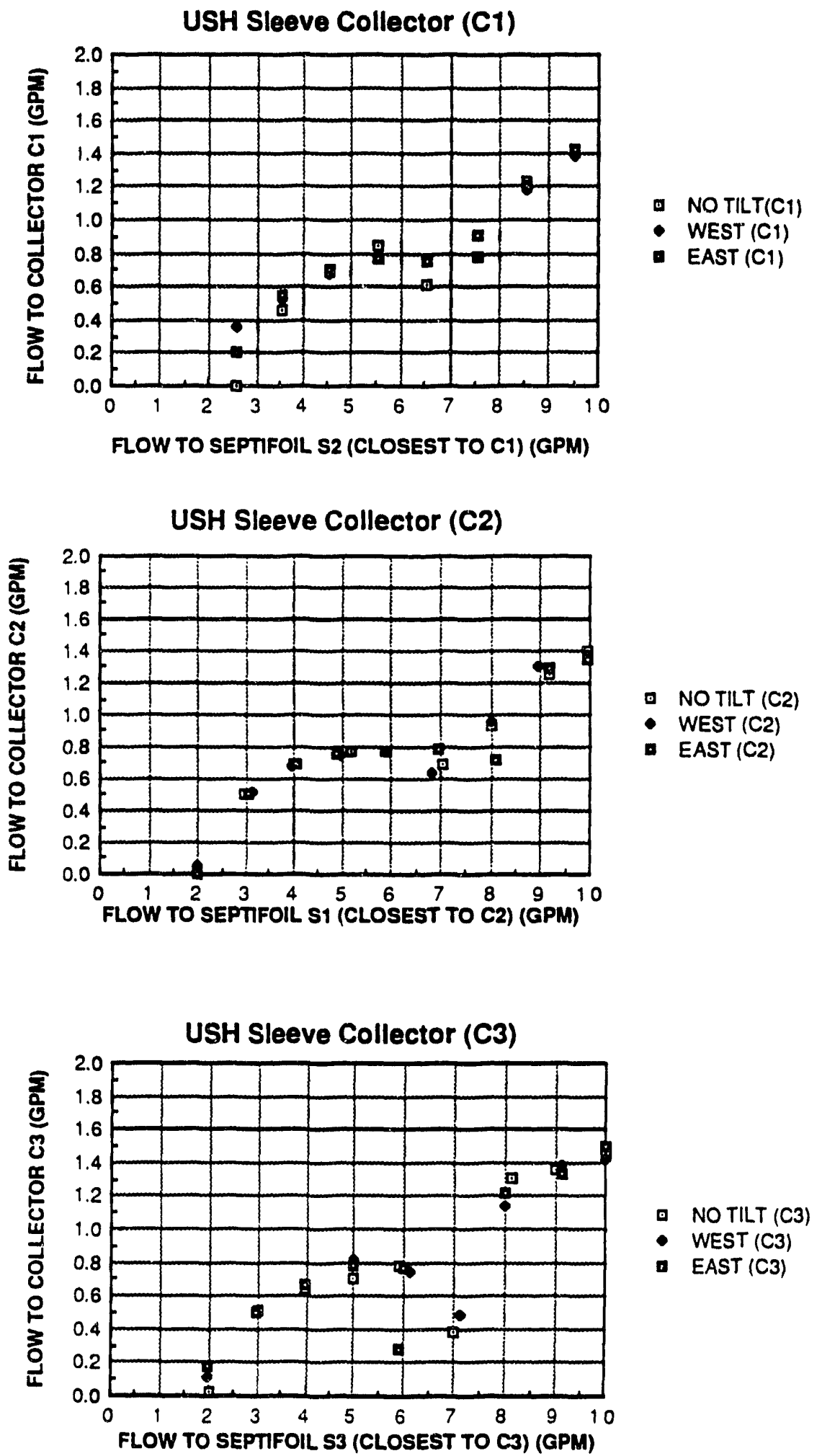

Figure 10: $\quad$ Effect of Tilt on USH Sleeve Collectors. 
ROTAMETER (M\&TE NO. TR-148)

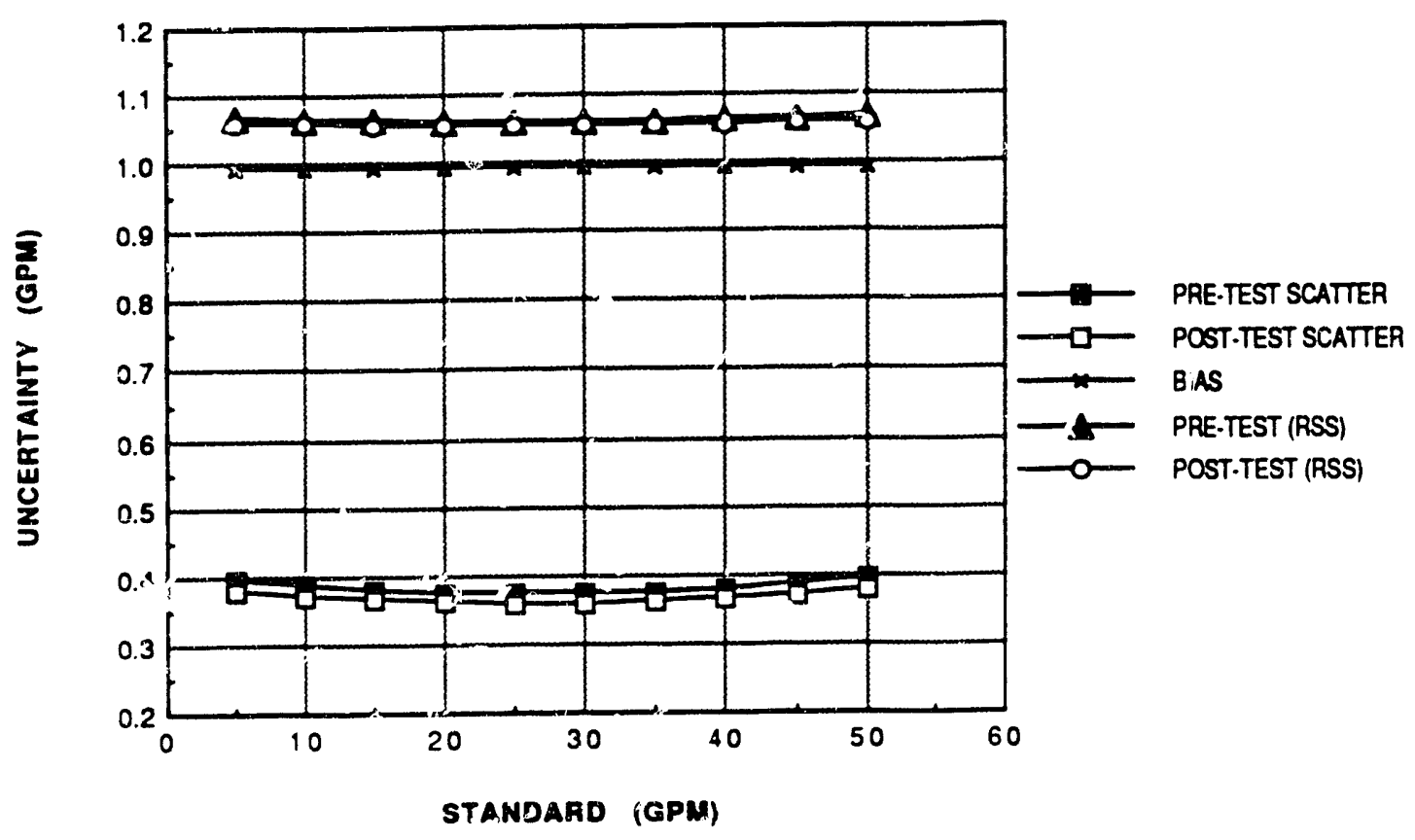

ROTAMETEF (M\&TE NO. TR-20276)

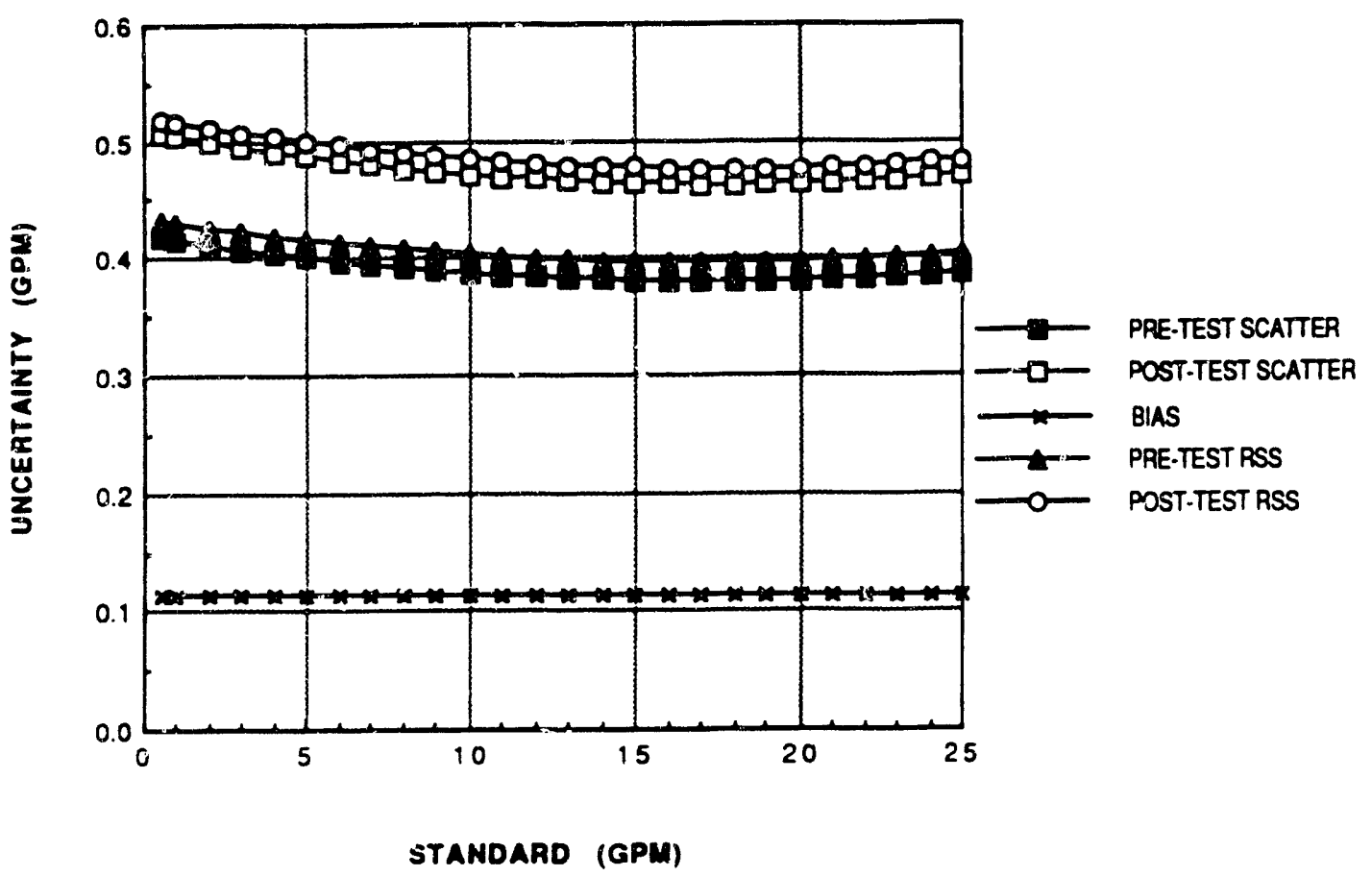

Figure 11: Uncertainty of Septifoil Flow rates (TR-148 and TR-20276). 

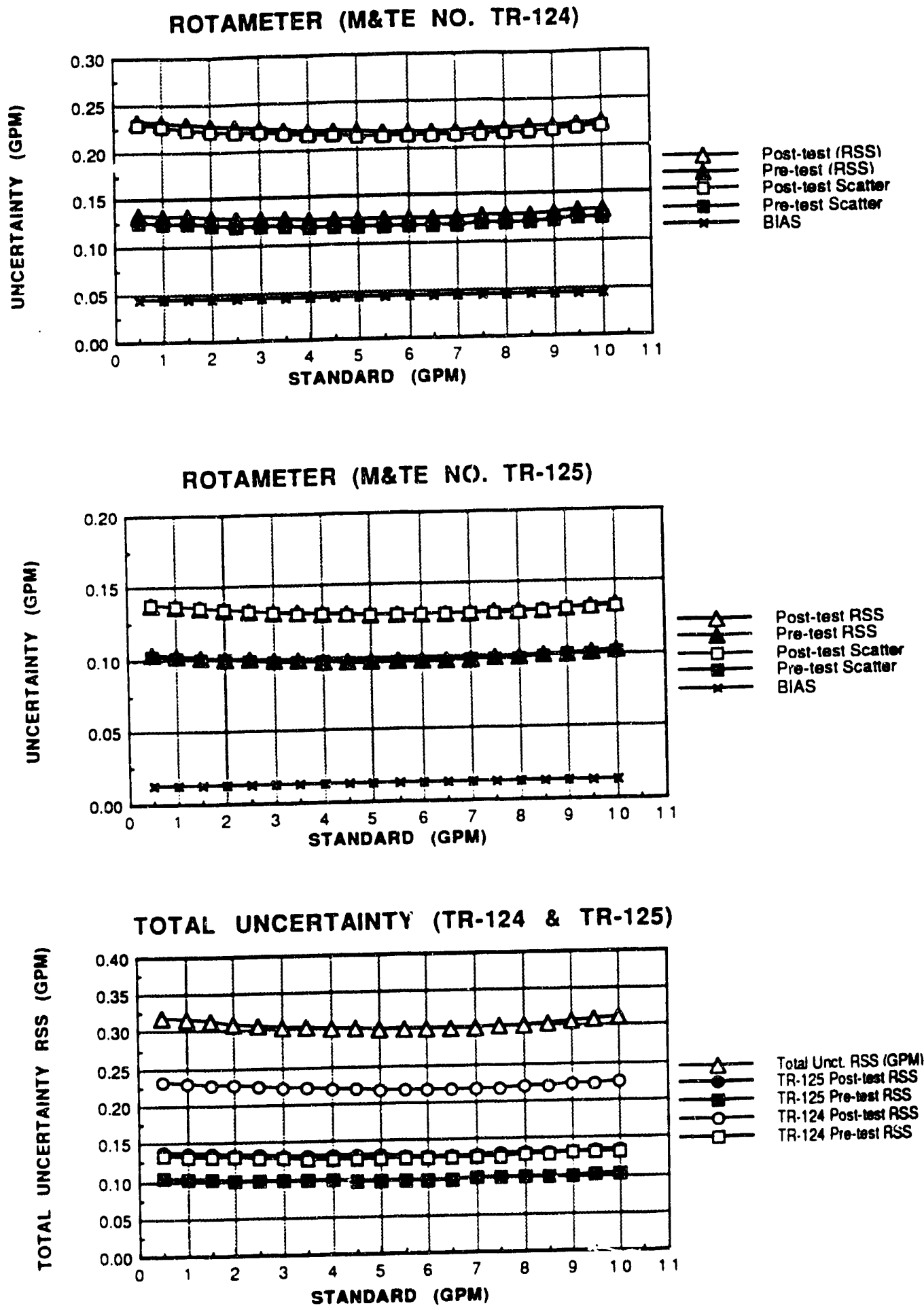

Figure 11: Uncertainty of Septifoil Flow rates (TR-124 and TR-125). 
Table I

No Tilt Data with Analysis.

\begin{tabular}{|c|c|c|c|c|c|c|c|c|c|c|}
\hline Aun & flnd. Flow $(\mathrm{mm})$ & Cal. Flow & ind flow (GPM) & Cal (GPM) & Ind llow $\%$ & Ce(OPM) & Ind $F_{\Lambda}=\%$ & $\mathrm{CA}(\rho \mathrm{pm})$ & Cal (GPM) & Ava. Sopt tor \\
\hline & Band 1 & OPM & Benk 2 & Bank 2 & Bank 3A(124) & Bank $3 A(124)$ & Bank So(125) & Bank 3B(125) & Bank 3 (lotal) & GAM \\
\hline & & Septifoll & & & & & & & & \\
\hline & & & & & & & & & & \\
\hline 1 & 27.00 & 1.98 & 2.00 & 2.56 & 17.10 & 2.00 & 0.00 & 0.00 & 2.00 & 2.18 \\
\hline 2 & 35.50 & 2.98 & 3.00 & 3.55 & 28.10 & 3.00 & 0.00 & 0.00 & 3.00 & 3.17 \\
\hline 3 & 44.50 & 4.00 & 4.00 & 4.55 & 35.00 & 3.90 & 0.00 & 0.00 & 3.99 & 4.18 \\
\hline 4 & 55.00 & 5.22 & 5.00 & 5.55 & 44.00 & 5.00 & 0.00 & 0.00 & 5.00 & 5.25 \\
\hline 5 & 61.00 & 5.91 & 6.00 & 6.54 & 52.00 & 5.80 & 0.00 & 0.00 & 5.80 & 6.12 \\
\hline$\theta$ & 71.00 & 7.07 & 7.00 & 7.54 & 62.00 & 7.00 & 0.00 & 0.00 & 7.00 & 7.21 \\
\hline 7 & 79.00 & 8.00 & 8.00 & 8.54 & 72.00 & 8.12 & 0.00 & 0.00 & 8.12 & 8.22 \\
\hline 8 & 89.00 & 9.16 & 9.00 & 9.53 & 80.00 & 9.01 & 0.00 & 0.00 & 9.01 & 9.23 \\
\hline 9 & 96.00 & 9.07 & 10.00 & 10.53 & 89.00 & 10.01 & 0.00 & 0.00 & 10.01 & 10.17 \\
\hline 10 & 113.00 & 11.94 & 12.00 & 12.52 & 53.00 & 6.00 & 53.00 & 5.80 & 11.89 & 12.12 \\
\hline 11 & 130.00 & 13.81 & 14.00 & 14.52 & 63.00 & 7.11 & 63.00 & 7.00 & 14.11 & 14.18 \\
\hline 12 & .48 .00 & 15.012 & 16.00 & 16.51 & 72.00 & 8.12 & 72.00 & 8.00 & 16.12 & 16.21 \\
\hline 131 & 165.00 & 17.98 & 18.00 & 18.30 & 81.00 & 9.12 & 81.00 & 9.00 & 18.12 & 19.19 \\
\hline 14 & 182.00 & 19.93 & 20.00 & 20.50 & 90.00 & 10.13 & 90.00 & 10.00 & 20.12 & 20.18 \\
\hline & & & & & & & & & & \\
\hline Pun 1 & Weight & Weight & Woight & Temp. & Oensity & Gallens & Gallons & Gallons & Min & Soc \\
\hline & $\mathrm{Cl}_{1}$ & $\mathrm{C2}$ & C3 & ${ }^{\circ} \mathrm{C}$ & Lo/cuft & $\mathrm{Cl}_{1}$ & C2 & C3 & & \\
\hline & & & & & & & & & & \\
\hline 1 & 1.20 & 5.18 & 6.74 & 21.20 & 62.30 & 0.14 & 0.62 & 0.81 & 24.00 & 45.00 \\
\hline 2 & 13.42 & 14.68 & 15.00 & 21.70 & 62.20 & 1.81 & 1.75 & 1.80 & 3.00 & 31.00 \\
\hline 3 & 12.98 & 12.70 & 11.80 & 21.70 & 62.29 & 1.56 & 1.53 & 1.43 & 2.00 & 14.00 \\
\hline 4 & 14.74 & 13.34 & 12.40 & 21.50 & 62.29 & 1.77 & 1.60 & 1.49 & 2.00 & 5.00 \\
\hline 5 & 11.08 & 15.16 & 15.18 & 29.30 & 62.20 & 1.44 & 1.82 & 1.82 & 2.00 & 20.00 \\
\hline 6 & 10.00 & 14.36 & 7.98 & 20.90 & 62.30 & 1.02 & 1.72 & 0.96 & 2.00 & 27.00 \\
\hline 7 & 14.06 & 11.44 & 16.08 & 20.80 & 62.30 & 1.80 & 1.37 & 1.93 & 1.00 & 28.00 \\
\hline 8 & 15.94 & 14.08 & 15.24 & 20.80 & 62.30 & 1.91 & 1.60 & 1.83 & 1.00 & 21.00 \\
\hline 9 & 14.86 & 13.84 & 14.10 & 20.00 & 62.30 & 1.78 & 1.68 & 1.73 & 1.00 & 11.00 \\
\hline 10 & 15.38 & 11.88 & 13.28 & 20.80 & 62.30 & 1.85 & 1.43 & 1.59 & 1.00 & 3.00 \\
\hline 11 & 16.56 & 12.72 & 6.72 & 20.80 & 62.30 & 1.99 & 1.53 & 0.81 & 1.00 & 7.00 \\
\hline 12 & 14.88 & 6.18 & 4.04 & 20.00 & 62.30 & 1.79 & 0.74 & 0.49 & 1.00 & 5.00 \\
\hline 13 & 13.58 & 8.58 & 1.36 & 20.70 & 62.30 & 1.63 & 1.03 & 0.18 & 1.00 & 8.00 \\
\hline 14 & 14.20 & 8.76 & 1.54 & 20.70 & 62.30 & 1.70 & 1.05 & 0.18 & 1.00 & 3.00 \\
\hline & & & & & & & & & & \\
\hline & & & & & & & & & & \\
\hline Aun & Time & GPM(C1) & GPM(C2) & GPM(C3) & Ava. & & & & & \\
\hline & (Min) & & & & & & & & & \\
\hline & & & & & & & & & & \\
\hline & 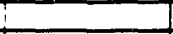 & & & & & & & & & \\
\hline 1 & 24.75 & 0.01 & 0.03 & 0.03 & 0.02 & & & & & \\
\hline 2 & 3.52 & 0.48 & 0.50 & 0.51 & 0.40 & & & & & \\
\hline 3 & 2.23 & 0.70 & 0.60 & 0.84 & 0.67 & & & & & \\
\hline 4 & 2.08 & 0.85 & 0.77 & 0.71 & 0.78 & & & & & \\
\hline 5 & 2.33 & 0.62 & 0.78 & 0.78 & 0.73 & & & & & \\
\hline 6 & 2.45 & 0.78 & 0.70 & 0.39 & 0.63 & & & & & \\
\hline 7 & 1.47 & 1.22 & 0.94 & 1.31 & 1.10 & & & & & \\
\hline 8 & 1.35 & 1.42 & 1.25 & 1.38 & 1.34 & & & & & \\
\hline 9 & 1.18 & 1.51 & 1.40 & 1.46 & 1.48 & & & & & \\
\hline 101 & 1.05 & 1.78 & 1.36 & 1.52 & 1.55 & & & & & \\
\hline 11 & 1.12 & 1.78 & 1.37 & 0.72 & 1.20 & & & & & \\
\hline 12 & 1.08 & 1.65 & 0.68 & 0.45 & 0.83 & & & & & \\
\hline 131 & 1.10 & 1.48 & 0.94 & 0.15 & 0.86 & & & & & \\
\hline 141 & 105 & 1.62 & 1.00 & 0.18 & 0.93 & & & & & \\
\hline
\end{tabular}


Table II

East Tilt (0.5" per 48") Data with Analysis.

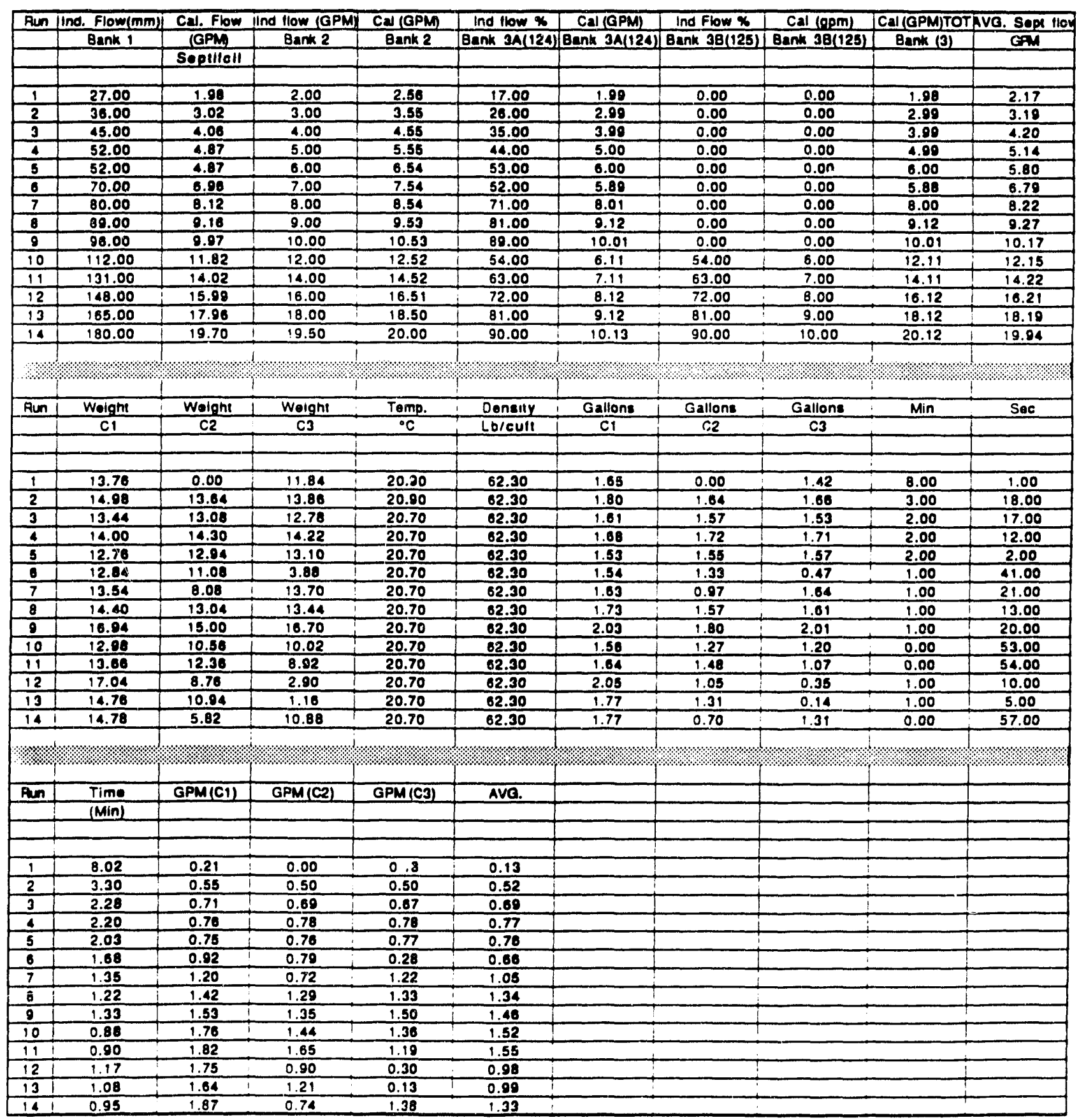


Table III

West Tilt (0.5" per 48") Data with Analysis.

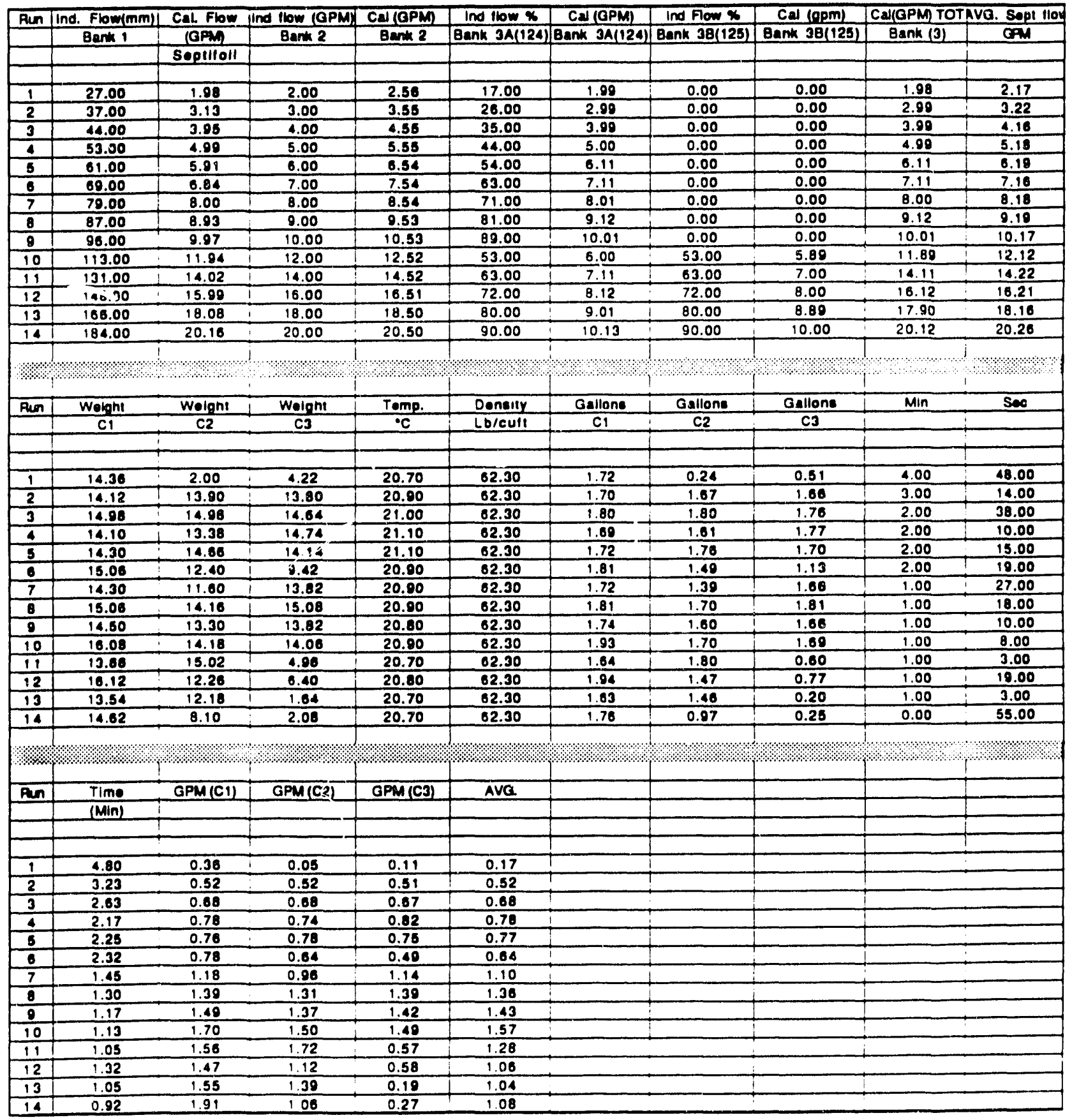


Table IV

Supplemental Data With Analysis.

\begin{tabular}{|c|c|c|c|c|c|c|c|c|c|c|c|c|c|}
\hline $\operatorname{Ain}$ & Ind. Flom (x) & Cal. Flow & Wolon & Tomp. & Deneity & Gallons & $\operatorname{Min}$ & Sec & Tlme & $G P M\left(C^{\circ}\right)$ & & & \\
\hline & Banik 1 & (GFin) & CI & ${ }^{\circ} \mathrm{C}$ & Lo/cuft & $C 1$ & & & $(M n)$ & & & & \\
\hline & & Sepilloll & & & & & & & & & & & \\
\hline & & & & & & & & & & & & & \\
\hline 1 & 20.00 & 2.26 & 14.68 & 24.70 & 02.25 & 1.78 & 4 & 29.70 & 4.50 & 0.30 & & & \\
\hline 2 & 25.00 & 2.80 & 20.14 & 24.70 & 62.25 & 2.42 & 5 & 4.02 & 5.07 & 0.48 & & & \\
\hline 3 & 30.00 & 3.34 & 17.20 & 24.70 & 62.26 & 2.07 & 3 & 38.24 & 3.64 & 0.57 & & & $i$ \\
\hline 4 & 35.00 & 3.88 & 19.04 & 24.80 & 62.25 & 2.20 & 3 & 27.71 & 3.16 & 0.68 & & & \\
\hline 5 & 40.00 & 4.42 & 20.34 & 24.30 & 62.25 & 2.44 & 3 & 18.80 & 3.31 & 0.74 & & & i \\
\hline 6 & 45.00 & 4.98 & 15.74 & 24.20 & 62.25 & 1.89 & 2 & 39.20 & 2.65 & 0.71 & & & \\
\hline 7 & 50.00 & 5.50 & 19.10 & 25.10 & 62.24 & 2.30 & 3 & 7.60 & 3.13 & 0.73 & & & \\
\hline 8 & 55.50 & 6.09 & 19.10 & 25.60 & 62.23 & 2.30 & 3 & 4.27 & 3.07 & 0.75 & & & \\
\hline 9 & 57.50 & 6.31 & 20.56 & 25.70 & 62.23 & 2.47 & 3 & 20.58 & 3.34 & 0.74 & & & \\
\hline 10 & 60.00 & 6.58 & 17.58 & 25.60 & 62.23 & 2.11 & 3 & 27.30 & 3.46 & 0.61 & & & 1 \\
\hline 11 & 62.50 & 6.85 & 19.44 & 25.30 & 62.24 & 2.34 & 4 & 31.58 & 4.53 & 0.52 & & & \\
\hline 12 & 65.00 & 7.12 & 19.70 & 25.20 & 62.24 & 2.37 & 5 & 23.10 & 5.39 & 0.44 & & & \\
\hline 13 & 67.50 & 7.39 & 20.08 & 24.80 & 62.24 & 2.41 & 4 & 38.59 & 4.84 & 0.52 & & & \\
\hline 14 & 70.00 & 7.68 & 21.84 & 24.80 & 62.24 & 2.62 & 3 & 30.45 & 3.51 & 0.75 & & & \\
\hline 15 & 72.50 & 7.03 & 22.12 & 21.30 & 62.29 & 2.60 & 2 & 51.04 & 2.87 & 0.93 & & & \\
\hline 16 & 75.00 & 8.20 & 18.84 & 21.30 & 62.20 & 2.20 & 2 & 8.53 & 2.14 & 1.06 & & & $i$ \\
\hline 17 & 80.00 & 8.74 & 22.68 & 21.30 & 62.29 & 2.72 & 2 & 50.20 & 2.90 & 0.91 & & & 1 \\
\hline & & & & & & & & & & & & & 1 \\
\hline & & & & & & & & & & & & & \\
\hline & & & & & & & & & & & & & \\
\hline & & & & & & & & & & & & & \\
\hline $\operatorname{Run}$ & Ind. Flow $(\%)$ & Col Flow & ind. Fom(\%) & Cal. Flow & Tolal & Weloht & Tomp. & Density & Qallons & $\operatorname{Min}$ & Sec & Time & GPM (C.e) \\
\hline & TR.125 & (GPM) & TA.124 & (GPM) & SEPTIFOIL & $c^{\cdots}$ & ${ }^{\circ} \mathrm{C}$ & Lolcutt & $C_{1}$ & & & (Min) & \\
\hline & & TA.126 & & TA.124 & Fomarm & & & & & & & & \\
\hline & & & & & & & & & & & & & \\
\hline 1 & 90.00 & 9.82 & 80.00 & 8.89 & 0.00 & 20.46 & 22.30 & 62.28 & 2.48 & 1.00 & 18.95 & 1.32 & 1.87 \\
\hline 2 & 90.00 & 9.82 & 90.00 & 9.08 & 18.71 & 21.12 & 24.40 & 02.25 & 2.34 & 0.00 & 56.38 & 0.94 & 2.70 \\
\hline 3 & 100.00 & 10.00 & 90.00 & 9.88 & 10.80 & 22.02 & 25.10 & 62.24 & 2.68 & 0.00 & 58.60 & 0.88 & 2.71 \\
\hline 4 & 100.00 & 10.00 & 100.00 & 11.07 & 20.88 & 20.98 & 21.50 & 62.20 & 2.32 & 0.00 & 51.61 & 0.86 & 2.03 \\
\hline 5 & 70.00 & 7.68 & 80.00 & 8.80 & 21.07 & 21.30 & 21.10 & 62.30 & 2.50 & 1.00 & 16.02 & 1.27 & 2.02 \\
\hline 6 & 60.00 & 6.50 & 60.00 & 6.71 & 16.55 & 22.24 & 21.00 & 62.30 & 2.67 & 1.00 & 25.82 & 1.43 & 1.86 \\
\hline 7 & 50.00 & 5.50 & 50.00 & 5.82 & 13.29 & 17.98 & 20.00 & 62.30 & 2.16 & 1.00 & 28.95 & 1.48 & 1.46 \\
\hline 8 & 0.00 & 0.10 & 80.00 & 8.89 & 11.12 & 20.22 & 20.90 & 62.30 & 2.43 & 1.00 & 45.98 & 1.77 & 1.37 \\
\hline 9 & 0.00 & 0.10 & 60.00 & 6.71 & 8.00 & 17.00 & 20.80 & 62.30 & 2.04 & 3.00 & 48.25 & 3.80 & 0.54 \\
\hline 10 & 00.00 & 9.82 & 80.00 & 8.80 & 8.81 & 20.20 & 20.80 & 62.30 & 2.43 & 1.00 & 6.13 & 1.10 & 2.20 \\
\hline 11 & 60.00 & 0.68 & 0.00 & 0.17 & 10.71 & 21.00 & 20.80 & 62.30 & 2.52 & 4.00 & 17.65 & 4.29 & 0.50 \\
\hline 12 & 70.50 & 7.71 & 0.00 & 0.17 & 6.76 & 21.78 & 20.90 & 02.30 & 2.02 & 2.00 & 16.40 & 2.27 & 1.15 \\
\hline 13 & 40.00 & 4.42 & 40.00 & 4.63 & 7.88 & 23.22 & 20.80 & 62.30 & 2.78 & 2.00 & 3.91 & 2.07 & 1.35 \\
\hline 14 & 50.00 & 5.50 & 40.00 & 4.83 & 8.95 & 23.32 & 20.90 & 62.30 & 2.80 & 1.00 & 53.45 & 1.89 & 1.48 \\
\hline 15 & 50.00 & 5.50 & 50.00 & 5.62 & 10.03 & 20.84 & 20.90 & 82.30 & 2.48 & 1.00 & 33.88 & 1.56 & 1.58 \\
\hline 18 & 60.00 & 6.58 & 50.00 & 5.62 & 11.12 & 19.52 & 21.00 & 62.30 & 2.34 & 1.00 & 40.59 & .68 & 1.40 \\
\hline 17 & 60.00 & 6.58 & 80.00 & 6.71 & 12.20 & 18.80 & 21.00 & 62.30 & 2.26 & 1.00 & 26.51 & 1.44 & 1.57 \\
\hline 18 & 70.00 & 7.66 & 60.00 & 8.71 & 13.20 & 23.90 & 21.00 & 62.30 & 2.87 & 1.00 & 41.54 & 1.69 & 1.70 \\
\hline 19 & 70.00 & 7.60 & 70.00 & 7.80 & 14.37 & 18.08 & 21.00 & 62.30 & 2.17 & 1.00 & 19.60 & 1.33 & 1.63 \\
\hline 20 & 80.00 & 8.74 & 70.00 & 7.80 & 15.46 & 23.30 & 21.30 & 62.20 & 2.80 & 1.00 & $\$ 9.12$ & 1.82 & 1.54 \\
\hline 21 & 80.00 & 8.74 & 80.00 & 8.89 & 16.54 & 18.14 & 21.30 & 02.29 & 2.18 & 1.00 & 3.98 & 1.07 & 2.04 \\
\hline
\end{tabular}




\section{Table V}

USH Collector Uncertainty Analysis, No Tilt.

\begin{tabular}{|c|c|c|c|c|c|c|c|}
\hline Woight (Lb) & Temp. $\left({ }^{\circ} \mathrm{C}\right)$ & Time (min) & Density (Lb/cult) & $\partial D / \partial T$ & Q for C1 (GPM) & \multicolumn{2}{|c|}{ OMEGA(Density) OMEGA(Collecior) } \\
\hline (C1) & & & & & & (Lb/cuft) & (GPM) \\
\hline & & & & & & & (C1) \\
\hline 1.20 & 21.20 & 24.75 & 62.30 & $-1.35 E .02$ & 0.01 & $1.38 \mathrm{E} .02$ & $5.08 \mathrm{E} .03$ \\
\hline 13.42 & 21.70 & 3.52 & 62.29 & $-1.38 E-02$ & 0.46 & 1.41E-02 & $3.35 E-02$ \\
\hline 12.98 & 21.70 & 2.23 & 62.29 & $-1.38 E-02$ & 0.70 & $1.41 \mathrm{E}-02$ & 7.09E-02 \\
\hline 14.74 & 21.50 & 2.08 & 62.29 & $-1.36 \mathrm{E}-02$ & 0.85 & $1.40 \mathrm{E}-02$ & $8.90 \mathrm{E}-02$ \\
\hline 11.98 & 21.30 & 2.33 & 62.28 & $-1.35 E-02$ & 0.62 & 1.39E-02 & $6.10 \mathrm{E}-02$ \\
\hline 16.00 & 20.90 & 2.45 & 62.30 & $-1.33 \mathrm{E}-02$ & 0.78 & $1.36 \mathrm{E}-02$ & $7.03 E-02$ \\
\hline 14.96 & 20.80 & 1.47 & 62.30 & $-1.32 E-02$ & 1.22 & $1.36 \mathrm{E}-02$ & $1.73 \mathrm{E}-01$ \\
\hline 15.94 & 20.80 & 1.35 & 62.30 & $-1.32 E-02$ & 1.42 & $1.36 \mathrm{E}-02$ & 2.17E-01 \\
\hline 14.86 & 20.80 & 1.18 & 62.30 & $.1 .32 E-02$ & 1.51 & $1.36 E-02$ & 2.63E-01 \\
\hline 15.38 & 20.80 & 1.05 & 62.30 & $-1.32 E-02$ & 1.76 & $1.36 \mathrm{E}-02$ & $3.42 \mathrm{E}-01$ \\
\hline 16.56 & 20.80 & 1.12 & 62.30 & $-1.32 E-02$ & 1.78 & $1.36 \mathrm{E}-02$ & $3.25 \mathrm{E}-01$ \\
\hline 14.88 & 20.80 & 1.08 & 62.30 & $.1 .32 E-02$ & 1.65 & $1.36 \mathrm{E} .02$ & 3.13E-01 \\
\hline 13.58 & 20.70 & 1.10 & 62.30 & $-1.32 E-02$ & 1.48 & 1.35E-02 & 2.77E-01 \\
\hline 14.20 & 20.70 & 1.05 & 62.30 & $-1.32 E \cdot 02$ & 1.62 & 1.35E-02 & 3.16E-01 \\
\hline & & & & & & & \\
\hline Weight (Lb) & Temp. $\left({ }^{\circ} \mathrm{C}\right)$ & Time (min) & Density (Lb/cuft) & $\partial D / \partial T$ & $Q$ tor $\mathrm{C2}$ (GPM) & OMEGA(Density) & OMEGA(Collector) \\
\hline (C2) & & & & & & (Lb/cuft) & (GPM) \\
\hline & & & & & & & (C2) \\
\hline 5.18 & 21.20 & 24.75 & 62.30 & $-1.35 E-02$ & 0.03 & $1.38 \mathrm{E}-02$ & 2.97E-03 \\
\hline 14.58 & 21.70 & 3.52 & 62.29 & $-1.38 E-02$ & 0.50 & 1.41E-02 & $3.52 E-02$ \\
\hline 12.76 & $\$ 1.70$ & 2.23 & 62.29 & $-1.38 E-02$ & 0.69 & 1.41E-02 & 6.97E-02 \\
\hline 13.34 & 21.50 & 2.08 & 62.29 & $-1.36 \mathrm{E}-02$ & 0.77 & $1.40 \mathrm{E}-02$ & $8.18 E-02$ \\
\hline 15.16 & 21.30 & 2.33 & 62.29 & $-1.35 E .02$ & 0.78 & 1.39E-02 & 7.39E-02 \\
\hline 14.36 & 20.90 & 2.45 & 62.30 & $-1.33 E-02$ & 0.70 & $1.36 E-02$ & $6.48 E .02$ \\
\hline 11.44 & 20.80 & 1.47 & 62.30 & $-1.32 E-02$ & 0.94 & 1.36E-02 & 1.37E-01 \\
\hline 14.08 & 20.80 & 1.35 & 62.30 & $-1.32 E-02$ & 1.25 & $1.36 \mathrm{E}-02$ & $1.93 E-01$ \\
\hline 13.84 & 20.80 & 1.18 & 62.30 & $-1.32 E-02$ & 1.40 & 1.36E-02 & 2.45E-01 \\
\hline 11.88 & 20.80 & 1.05 & 62.30 & $-1.32 E-02$ & 1.36 & 1.36E-02 & 2.68E.01 \\
\hline 12.72 & 20.80 & 1.12 & 62.30 & $-1.32 E-02$ & 1.37 & 1.36E-02 & 2.54E-01 \\
\hline 6.16 & 20.80 & 1.08 & 62.30 & $-1.32 E-02$ & 0.68 & $1.36 \mathrm{E} \cdot 02$ & $1.43 \mathrm{E}-01$ \\
\hline 8.58 & 20.70 & 1.10 & 62.30 & $-1.32 E-02$ & 0.94 & $1.35 E-02$ & 1.83E-01 \\
\hline 8.76 & 20.70 & 1.05 & 62.30 & $-1.32 E-02$ & 1.00 & 1. $35 \mathrm{E}-02$ & 2.03E-01 \\
\hline & & & & & & & \\
\hline Woight (Lb) & Temp. $\left({ }^{\circ} \mathrm{C}\right)$ & Time $(\mathrm{min})$ & Density (Lb/cult) & $\partial D / \partial T$ & O for C3 (GPM) & OMEGA(Density) & OMEGA(Collector) \\
\hline (C3) & & & & & & (Lb/culI) & (GPM) \\
\hline & & & & & & & $(\mathrm{C} 3)$ \\
\hline 6.74 & 21.20 & 24.75 & 62.30 & $-1.35 E-02$ & 0.03 & $1.38 E-02$ & $2.97 E-03$ \\
\hline 15.00 & 21.70 & 3.52 & 62.29 & $-1.38 E-02$ & 0.51 & $1.41 E .02$ & $3.58 \mathrm{E}-02$ \\
\hline 11.80 & 21.70 & 2.23 & 62.29 & $-1.38 \mathrm{E}-02$ & 0.64 & 1.41E-02 & $6.60 \mathrm{E}-02$ \\
\hline 12.40 & 27.50 & 2.08 & 62.29 & $-1.36 \mathrm{E}-02$ & 0.71 & $1.40 \mathrm{E}-02$ & $7.71 \mathrm{E}-02$ \\
\hline 15.16 & 21.30 & 2.33 & 62.29 & $-1.35 E-02$ & 0.78 & $1.39 \mathrm{E}-02$ & 7.39E-02 \\
\hline 7.96 & 20.90 & 2.45 & 62.30 & $-1.33 E-02$ & 0.39 & $1.36 \mathrm{E}-02$ & 4.37E-02 \\
\hline 16.06 & 20.80 & 1.47 & 62.30 & $-1.32 E-02$ & 1.31 & $1.36 \mathrm{E}-02$ & $1.86 \mathrm{E}-01$ \\
\hline 15.24 & 20.80 & 1.35 & 62.30 & $-1.32 E-02$ & 1.36 & $1.36 \mathrm{E}-02$ & $2.08 E-01$ \\
\hline 14.40 & 20.80 & 1.18 & 62.30 & $-1.32 E-02$ & 1.46 & $1.36 \mathrm{E}-02$ & 2.55E-01 \\
\hline 13.28 & 20.80 & 1.05 & 62.30 & $-1.32 E-02$ & 1.52 & $1.36 \mathrm{E}-02$ & $2.98 \mathrm{E}-01$ \\
\hline 6.72 & 20.80 & 1.12 & 62.30 & $-1.32 \mathrm{E}-02$ & 0.72 & $1.36 \mathrm{E}-02$ & $1.45 \mathrm{E}-01$ \\
\hline 4.04 & 20.80 & 1.08 & 62.30 & $-1.32 E-02$ & 0.45 & $1.36 \mathrm{E}-02$ & 1.07E-01 \\
\hline 1.36 & 20.70 & 1.10 & 62.30 & $-1.32 E-02$ & 0.15 & 1.35E-02 & $7.18 \mathrm{E}-02$ \\
\hline 1.54 & 20.70 & 1.05 & 62.30 & $-1.32 E-02$ & 0.18 & 1.35E-02 & $7.74 E-02$ \\
\hline
\end{tabular}




\section{Table VI}

\section{USH Collector Uncertainty Analysis, East Tilt.}

\begin{tabular}{|c|c|c|c|c|c|c|c|}
\hline Woight (Lb) & Temp. $\left({ }^{\circ} \mathrm{C}\right)$ & Time (min) & Density (Lb/cuft) & DD/DT & $O$ tor $C 1$ (GPM) & OMEGA(Density) & OMEGA(Collector) \\
\hline (C1) & & & & & & (Lb/cult) & (GPM) \\
\hline & & & & & & & (C1) \\
\hline 13.76 & 20.90 & 8.02 & 62.30 & $-1.33 E-02$ & 0.21 & $1.36 \mathrm{E}-02$ & $1.05 \mathrm{E} .02$ \\
\hline 14.98 & 20.90 & 3.30 & 62.30 & $-1.33 E-02$ & 0.55 & $1.36 \mathrm{E}-02$ & $3.98 \mathrm{E}-02$ \\
\hline 13.44 & 20.70 & 2.28 & 62.30 & $-1.32 E-02$ & 0.71 & $1.35 \mathrm{E}-02$ & $6.97 E .02$ \\
\hline 14.00 & 20.70 & 2.20 & 62.30 & $-1.32 E-02$ & 0.76 & $1.35 \mathrm{E}-02$ & $7.70 \mathrm{E}-02$ \\
\hline 12.76 & 20.70 & 2.03 & 62.30 & $-1.32 E .02$ & 0.75 & $1.35 \mathrm{E}-02$ & B.24E.02 \\
\hline 12.84 & 20.70 & 1.68 & 62.30 & $-1.32 E-02$ & 0.92 & $1.35 \mathrm{E}-02$ & $1.17 \mathrm{E}-01$ \\
\hline 13.54 & 20.70 & 1.35 & 62.30 & $-1.32 E-02$ & 1.20 & $1.35 \mathrm{E}-02$ & $1.86 \mathrm{E} \cdot 01$ \\
\hline 14.40 & 20.70 & 1.22 & 62.30 & $-1.32 E-02$ & 1.42 & 1.35E.02 & 2.41E.01 \\
\hline 16.94 & 20.70 & 1.33 & 62.30 & $-1.32 E-02$ & 1.53 & $1.35 E-02$ & $2.35 E-01$ \\
\hline 12.98 & 20.70 & 0.88 & 62.30 & $-1.32 E .02$ & 4.76 & $1.35 \mathrm{E}-02$ & $4.08 \mathrm{E} .01$ \\
\hline 13.66 & 20.70 & 0.90 & 62.30 & -1.32 E-02 & 1.82 & $1.35 \mathrm{E}-02$ & $4.13 E-01$ \\
\hline 17.04 & 20.70 & 1.17 & 62.30 & $-1.32 E-02$ & 1.75 & $1.35 \mathrm{E}-02$ & $3.07 E-01$ \\
\hline 14.76 & 20.70 & 1.08 & 62.30 & $-1.32 \mathrm{E}-02$ & 1.64 & $1.35 \mathrm{E}-02$ & $3.08 \mathrm{E}-01$ \\
\hline 14.78 & 20.70 & 0.95 & 62.30 & $-1.32 E-02$ & 1.87 & $1.35 \mathrm{E}-02$ & 4.01E-01 \\
\hline & & & & & & & \\
\hline Woight (Lb) & Temp. $\left({ }^{\circ} \mathrm{C}\right)$ & Time (min) & Density (Lb/cuff) & $\partial D / \partial T$ & Q lor C2 (GPM) & OMEGA(Density) & OMEGA(Collector) \\
\hline (C2) & & & & & & ('b/culi) & (GPM) \\
\hline & & & & & & & $\left(\mathrm{C}_{2}\right)$ \\
\hline 0.00 & 20.80 & 8.02 & 62.30 & $-1.33 E-02$ & 0.00 & $1.36 \mathrm{E}-02$ & $0.00 \mathrm{E}+00$ \\
\hline 13.64 & 20.90 & 3.30 & 62.30 & $-1.33 E \cdot 02$ & 0.50 & $1.36 \mathrm{E}-02$ & $3.74 E .02$ \\
\hline 13.08 & 20.70 & 2.28 & 62.30 & $-1.32 E-02$ & 0.68 & $1.35 \mathrm{E}-02$ & $6.83 E-02$ \\
\hline 14.30 & 20.70 & 2.20 & 62.30 & $-1.32 E-02$ & 0.78 & $1.35 \mathrm{E} .02$ & $7.84 E-02$ \\
\hline 12.94 & 20.70 & 2.03 & 62.30 & $-1.32 E-02$ & 0.76 & 1.35E-02 & $8.33 E-02$ \\
\hline 11.08 & 20.70 & 1.68 & 62.30 & $-1.32 \mathrm{E}-02$ & 0.78 & $1.35 E-02$ & $1.03 E-01$ \\
\hline 8.08 & 20.70 & 1.35 & 62.30 & $-1.32 E-02$ & 0.72 & $1.35 \mathrm{E}-02$ & $1.10 \mathrm{E}-01$ \\
\hline 13.04 & 20.70 & 1.22 & 62.30 & $-1.32 E-02$ & 1.29 & $1.35 E-02$ & $2.20 E-01$ \\
\hline 15.00 & 20.70 & 1.33 & 62.30 & $-1.32 E-02$ & 1.35 & $1.35 \mathrm{E}-02$ & $2.10 \mathrm{E}-01$ \\
\hline 10.56 & 20.70 & 0.88 & 62.30 & $-1.32 E-02$ & 1.44 & $1 . \overline{35 E-02}$ & $3.35 E-01$ \\
\hline 12.36 & 20.70 & 0.90 & 62.30 & $-1.32 E-02$ & 1.65 & $1.35 \mathrm{E}-02$ & $3.75 E .01$ \\
\hline 8.76 & 20.70 & 1.17 & 62.30 & $-1.32 E-02$ & 0.90 & $1.35 E-02$ & 1.67 E.01 \\
\hline 10.94 & 20.70 & 1.08 & 62.30 & $-1.32 \mathrm{E} .02$ & 1.21 & $1.35 \mathrm{E}-02$ & $2.34 E-01$ \\
\hline 5.82 & 20.70 & 0.95 & 62.30 & $-1.32 E-02$ & 0.74 & $1.35 E-02$ & $1.73 E-01$ \\
\hline & & & & & & & \\
\hline Woight (Lb) & Temp. $\left({ }^{\circ} \mathrm{C}\right)$ & Time (min) & Density (Lb/cuft) & $\partial D / \partial T$ & $Q$ for C3 (GPM) & OMEGA(Density) & OMEGA(Collector) \\
\hline (C3) & & & & & & (Lb/cuft) & (GPM) \\
\hline & & & & & & & (c3) \\
\hline 11.84 & 20.90 & 8.02 & 62.30 & $-1.33 E-02$ & 0.18 & $1.36 \mathrm{E}-02$ & 1.02E-02 \\
\hline 13.86 & 20.80 & 3.30 & 62.30 & $-1.33 E-02$ & 0.50 & 1.36E-02 & $3.78 E-02$ \\
\hline 12.78 & 20.70 & 2.28 & 62.30 & $-1.32 E-02$ & 0.67 & 1.35E-02 & $6.70 \mathrm{E}-02$ \\
\hline 14.22 & 20.70 & 2.20 & 62.30 & $-1.32 \mathrm{E}-02$ & 0.78 & $1.35 \mathrm{E}-02$ & $7.80 E-02$ \\
\hline 13.10 & 20.70 & 2.03 & 62.30 & $-1.32 E-02$ & 0.77 & $1.35 \mathrm{E} .02$ & $8.12 E-02$ \\
\hline 3.88 & 20.70 & 1.68 & 62.30 & $-1.32 E-02$ & 0.28 & $1.35 \mathrm{E}-02$ & $5.45 \mathrm{E}-02$ \\
\hline 13.70 & 20.70 & 1.35 & 62.30 & $-1.32 E \cdot 02$ & 1.22 & 1.35E-02 & 1.88E-01 \\
\hline 13.44 & 20.70 & 1.22 & 62.30 & $-1.32 E-02$ & 1.33 & 1.35E-02 & 2.26E-01 \\
\hline 16.70 & 20.70 & 1.33 & 62.30 & $.1 .32 E .02$ & 1.50 & $1.35 \mathrm{E}-02$ & $2.32 E-01$ \\
\hline 10.02 & 20.70 & 0.88 & 62.30 & $-1.32 E-02$ & 1.36 & $1.35 E-02$ & $3.18 \mathrm{E}-01$ \\
\hline 8.92 & 20.70 & 0.90 & 62.30 & $-1.32 \mathrm{E}-02$ & 1.19 & $1.35 \mathrm{E}-02$ & 2.77E-01 \\
\hline 2.90 & 20.70 & 1.17 & 62.30 & $-1.32 E-02$ & 0.30 & $1.35 \mathrm{E}-02$ & $8.10 \mathrm{E}-02$ \\
\hline 1.16 & 20.70 & 1.08 & 62.30 & $-1.32 \mathrm{E}-02$ & 0.13 & $1.35 \mathrm{E}-02$ & $7.17 E-02$ \\
\hline 10.88 & 20.70 & 0.95 & 62.30 & $-1.32 E-02$ & 1.38 & $1.35 \mathrm{E} .02$ & $3.00 \mathrm{E}-01$ \\
\hline
\end{tabular}




\section{Table VII}

\section{USH Collector Uncertainty Analysis, West Tilt.}

\begin{tabular}{|c|c|c|c|c|c|c|c|}
\hline Weight (Lb) & Tomp. $\left({ }^{\circ} \mathrm{C}\right)$ & Time (min) & Density (Lb/cuff) & $\partial D / \partial T$ & Q tor C1 (GPM) & OMEGA(Density) & OMEGA(Collecior \\
\hline (C1) & & & & & & (Lb/cult) & (GPM) \\
\hline & & & & & & & (C1) \\
\hline 14.36 & 20.70 & 4.80 & 62.30 & $-1.32 E-02$ & 0.36 & $1.35 \mathrm{E} \cdot 02$ & $2.14 \mathrm{E} .02$ \\
\hline 14.12 & 20.80 & 3.23 & 62.30 & $-1.33 \mathrm{E}-02$ & 0.52 & $1.36 E-02$ & $3.96 \mathrm{E}-02$ \\
\hline 14.98 & 21.00 & 2.63 & 62.30 & $-1.33 E-02$ & 0.68 & 1.37E.02 & $5.89 E-02$ \\
\hline 14.10 & 21.10 & 2.17 & 62.30 & $-1.34 E-02$ & 0.78 & $1.37 E-02$ & $7.97 E-02$ \\
\hline 14.30 & 21.10 & 2.25 & 62.30 & -1.34 E.02 & 0.76 & 1.37E-02 & $7.52 E .02$ \\
\hline 15.06 & 20.90 & 2.32 & 62.30 & $.1 .33 \mathrm{E}-02$ & 0.78 & $1.36 E \cdot 02$ & $7.44 E .02$ \\
\hline 14.30 & 20.90 & 1.45 & 62.30 & $.1 .33 \mathrm{E}-02$ & 1.18 & $1.36 \mathrm{E}-02$ & $1.71 \mathrm{E} .01$ \\
\hline 15.06 & 20.80 & 1.30 & 62.30 & $-1.33 E-02$ & 1.39 & $1.36 \mathrm{E}-02$ & $2.21 E .01$ \\
\hline 14.50 & 20.80 & 1.17 & 62.30 & $-1.32 E-02$ & 1.49 & $1.36 \mathrm{E}-02$ & $2.63 \mathrm{E}-01$ \\
\hline 16.08 & 20.80 & 1.13 & 62.30 & $-1.33 \mathrm{E} .02$ & 1.70 & $1.36 \mathrm{E}-02$ & $3.08 E \cdot 01$ \\
\hline 13.66 & 20.70 & 1.05 & 62.30 & $-1.32 \mathrm{E} \cdot 02$ & 1.56 & $1.35 E .02$ & $3.06 \mathrm{E}-01$ \\
\hline 16.12 & 20.80 & 1.32 & 62.30 & $-1.32 \mathrm{E}-02$ & 1.47 & $1.36 \mathrm{E}-02$ & $2.30 E-01$ \\
\hline 13.54 & 20.70 & 1.05 & 62.30 & $-1.32 E-02$ & 1.55 & $1.35 \mathrm{E}-02$ & $3.03 E-01$ \\
\hline 14.62 & 20.70 & 0.92 & 62.30 & $-1.32 \mathrm{E} .02$ & 1.91 & $1.35 \mathrm{E}-02$ & 4.25E-01 \\
\hline & & & & & & & \\
\hline Woight (Lb) & Temp. $\left({ }^{\circ} \mathrm{C}\right)$ & $\operatorname{Time}(\min )$ & Densily (Lb/cuff) & $\partial D / \partial T$ & 0 lor C2 (GPM) & OMEGA(D ensity) & OMEGA Collector \\
\hline (C2) & & & & & & (Lb/culi) & (GPM) \\
\hline & & & & & & & (C2) \\
\hline 2.00 & 20.70 & 4.80 & 62.30 & $-1.32 E-02$ & 0.05 & $1.35 \mathrm{E} .02$ & $1.54 E-02$ \\
\hline 13.90 & 20.90 & 3.23 & 62.30 & $-1.33 E-02$ & 0.52 & $1.36 E \cdot 02$ & $3.91 E .02$ \\
\hline 14.98 & 21.00 & 2.63 & 62.30 & $-1.33 E .02$ & 0.68 & $1.37 \mathrm{E}-02$ & 5.89E-02 \\
\hline 13.38 & 21.10 & 2.17 & 62.30 & $-1.34 E \cdot 02$ & 0.74 & $1.37 E .02$ & $7.63 E-02$ \\
\hline 14.66 & 21.10 & 2.25 & 62.30 & $-1.34 E \cdot 02$ & 0.78 & $1.37 E .02$ & $7.68 E .02$ \\
\hline 12.40 & 20.80 & 2.32 & 62.30 & $.1 .33 E \cdot 02$ & 0.64 & $1.36 \mathrm{E} .02$ & $6.39 \mathrm{E} \cdot 02$ \\
\hline 11.60 & 20.90 & 1.45 & 62.30 & $-1.33 E-02$ & 0.96 & $1.36 \mathrm{E}-02$ & $1.42 E .01$ \\
\hline 14.16 & 20.80 & 1.30 & 62.30 & $-1.33 \mathrm{E}-02$ & 1.31 & $1.36 \mathrm{E}-02$ & $2.09 E-01$ \\
\hline 13.30 & 20.80 & 1.17 & 62.30 & $-1.32 \mathrm{E}-02$ & 1.37 & 1.36E.02 & $2.43 E-01$ \\
\hline 14.18 & 20.80 & 1.13 & 62.30 & $-1.33 E-02$ & 1.50 & $1.36 \mathrm{E} .02$ & $2.73 \mathrm{E}-01$ \\
\hline 15.02 & 20.70 & 1.05 & 62.30 & $-1.32 \varepsilon .02$ & 1.72 & $1.35 \mathrm{E}-02$ & $3.35 \mathrm{E}-01$ \\
\hline 12.26 & 20.80 & 1.32 & 62.30 & $-1.32 E-02$ & 1.12 & $1.36 \mathrm{E}-02$ & $1.79 E-01$ \\
\hline 12.18 & 20.70 & 1.05 & 62.30 & $-1.32 E-02$ & 1.39 & $1.35 \mathrm{E} \cdot 02$ & $2.74 \mathrm{E}-01$ \\
\hline 8.10 & 20.70 & 0.92 & 62.30 & $-1.32 E \cdot 02$ & 1.06 & $1.35 \mathrm{E}-02$ & $2.45 E-01$ \\
\hline & & & & & & & \\
\hline Woight (Lb) & Tomp. $\left({ }^{\circ} \mathrm{C}\right)$ & $\operatorname{Time}(\min )$ & Densily (Lt/cuth) & $\partial D / \partial T$ & Q lor C3 (GPM) & OMEGA(Density) & OMEGA(Collector) \\
\hline (C3) & & & & & & (Lb/cull) & (GPM) \\
\hline & & & & & & & (C3) \\
\hline 4.22 & 20.70 & 4.80 & 62.30 & $-1.32 E-02$ & 0.11 & $1.35 \mathrm{E}-02$ & $1.59 E-02$ \\
\hline 13.80 & 20.00 & 3.23 & 62.30 & $-1.33 E-02$ & 0.51 & $1.36 E-02$ & $3.90 E \cdot 02$ \\
\hline 14.64 & 21.00 & 2.63 & 62.30 & $-1.33 \mathrm{E} \cdot 02$ & 0.67 & $1.37 E-02$ & $5.78 E-02$ \\
\hline 14.74 & 21.10 & 2.17 & 62.30 & $.1 .34 \mathrm{E} .02$ & 0.82 & $1.37 E .02$ & $8.26 E .02$ \\
\hline 14.14 & 21.10 & 2.25 & 62.30 & $-1.34 E \cdot 02$ & 0.75 & $1.37 \mathrm{E}-02$ & $7.46 E-02$ \\
\hline 9.42 & 20.90 & 2.32 & 62.30 & $-1.33 \mathrm{E} \cdot 02$ & 0.49 & $1.36 \mathrm{E} .02$ & 5.27E-02 \\
\hline 13.82 & 20.80 & 1.45 & 62.30 & $-1.33 \mathrm{E} .02$ & 1.14 & $1.36 \mathrm{E}-02$ & $1.66 \mathrm{E}-01$ \\
\hline 15.08 & 20.00 & 1.30 & 62.30 & $.1 .33 E-02$ & 1.39 & $1.36 \mathrm{E}-02$ & $2.22 E-01$ \\
\hline 13.82 & 20.80 & 1.17 & 62.30 & $-1.32 \mathrm{E} .02$ & 1.42 & $1.36 \mathrm{E}-02$ & $2.52 \mathrm{E}-01$ \\
\hline 14.06 & 20.90 & 1.13 & 62.30 & $-1.33 \mathrm{E} \cdot 02$ & 1.49 & $1.36 \mathrm{E}-02$ & $2.71 \mathrm{E} .01$ \\
\hline 4.96 & 20.70 & 1.05 & 62.30 & $-1.32 \mathrm{E} \cdot 02$ & 0.57 & $1.35 \mathrm{E}-02$ & $1.29 E-01$ \\
\hline 6.40 & 20.80 & 1.32 & 62.30 & $-1.32 \mathrm{E} \cdot 02$ & 0.58 & $1.36 \mathrm{E} \cdot 02$ & $1.05 \mathrm{E} \cdot 01$ \\
\hline 1.64 & 20.70 & 1.05 & 62.30 & $-1.32 E-02$ & 0.19 & $1.35 \mathrm{E}-02$ & $7.84 \mathrm{E}-02$ \\
\hline 2.08 & 20.70 & 0.92 & 62.30 & $-1.32 E-02$ & 0.27 & $1.35 E .02$ & $9.96 \mathrm{E}-02$ \\
\hline
\end{tabular}




\section{Table VIII}

Supplemental Data Collector $\left(\mathrm{C}^{*} \& \mathrm{C}^{* *}\right)$ Uncertainty Analysis.

\begin{tabular}{|c|c|c|c|c|c|c|c|c|}
\hline Ann & Wenth! (Lb) & Temo. $\left({ }^{\circ} \mathrm{C}\right)$ & Time $(m i n)$ & Deneity (Lo/cult) & DO/JT & Q bor C $\mathrm{C}^{\circ}$ and $\mathrm{C}^{\circ-}$ & OMEQNDEnaly) & OMECA(Colbetor) \\
\hline & & & & & & (OPM) & (Lb/cuft) & (CPM) \\
\hline & & & & & & & & \\
\hline 1 & 14.68 & 24.70 & 4.50 & 62.28 & $.1 .56 E .02$ & 0.30 & $1.58 E-02$ & 0.03 \\
\hline 2 & 20.14 & 24.70 & 5.07 & 62.25 & $.1 .55 E \cdot 02$ & 0.48 & $1.58 E-02$ & 0.03 \\
\hline 3 & 17.26 & 24.70 & 3.64 & 62.26 & $-1.56 E .02$ & 0.57 & $1.50 E .02$ & 0.08 \\
\hline 4 & 10.04 & 24.80 & 3.48 & 62.26 & $.1 .64 E .02$ & 0.68 & $1.57 \mathrm{E} .02$ & 0.05 \\
\hline 5 & 20.34 & 24.30 & 3.31 & 62.25 & $.1 .63 E \cdot 02$ & 0.74 & $1.56 E .02$ & 0.08 \\
\hline 6 & 15.74 & 24.20 & 2.05 & 62.25 & $.1 .52 E .02$ & 0.71 & $1.55 E .02$ & 0.07 \\
\hline 7 & 19.10 & 25.10 & 3.13 & 62.24 & $-1.57 E \cdot 02$ & 0.73 & $1.60 E .02$ & 0.08 \\
\hline 8 & 19.10 & 25.60 & 3.07 & 62.23 & $-1.60 E \cdot 02$ & 0.75 & 1.63E.02 & 0.06 \\
\hline 9 & 20.56 & 25.70 & 3.34 & 62.23 & $.1 .61 \mathrm{E} .02$ & 0.74 & $1.63 E .02$ & 0.08 \\
\hline 10 & 17.58 & 25.60 & 3.46 & 62.23 & $.1 .60 E .02$ & 0.61 & $1.03 E .02$ & 0.05 \\
\hline 11 & 19.44 & 25.30 & 4.53 & 62.24 & $-1.58 E .02$ & 0.52 & $1.61 \mathrm{E} .02$ & 0.04 \\
\hline 12 & 19.70 & 25.20 & 5.30 & 52.24 & $.1 .58 E-02$ & 0.44 & $1.61 E .02$ & 0.03 \\
\hline 13 & 20.06 & 24.80 & 4.64 & 62.24 & $.1 .58 E .02$ & 0.52 & $1.30 E .02$ & 0.03 \\
\hline 14 & 21.04 & 24.80 & 3.51 & 62.24 & $.1 .55 \mathrm{E} \cdot 02$ & 0.75 & 1.58E.02 & 0.08 \\
\hline 15 & 22.12 & 21.30 & 2.87 & 62.20 & $-1.36 \mathrm{E} .02$ & 0.03 & 1.30E-02 & 0.08 \\
\hline 16 & 10.84 & 21.30 & 2.14 & 62.20 & $.1 .35 E-02$ & 1.08 & $1.30 E .02$ & 0.11 \\
\hline 17 & 22.68 & 21.30 & 2.00 & 62.29 & $-1.35 E .02$ & 0.01 & $1.30 E .02$ & 0.07 \\
\hline 1 & 20.48 & 22.30 & 1.32 & 62.20 & $-1.41 E .02$ & 1.87 & 1.44E.02 & 0.30 \\
\hline 2 & 21.12 & 24.10 & 0.04 & 62.25 & $-1.53 E-02$ & 2.70 & 1.56E-02 & 0.50 \\
\hline 3 & 22.02 & 25.10 & 0.08 & 62.24 & $.1 .57 \mathrm{E} .02$ & 2.71 & $1.00 E .02$ & 0.87 \\
\hline 4 & 20.00 & 21.60 & 0.88 & 62.20 & $.1 .36 E .02$ & 2.93 & $1.10 \mathrm{E} .02$ & 0.60 \\
\hline 5 & 21.30 & 21.10 & 1.27 & 62.30 & $.1 .34 E .02$ & 2.02 & $1.37 E .02$ & 0.33 \\
\hline 6 & 22.21 & 21.00 & 143 & 62.30 & $-1.33 E \cdot 02$ & 1.86 & $1.37 \mathrm{E} .02$ & 0.27 \\
\hline 7 & 17.08 & 20.90 & 1.48 & 62.30 & $-1.33 E .02$ & 1.46 & $1.36 E .02$ & 0.21 \\
\hline 8 & 20.22 & 20.90 & 1.77 & 62.30 & $.1 .33 \mathrm{E}-02$ & 1.37 & $1.36 E .02$ & 0.17 \\
\hline 9 & 17.00 & 20.00 & 3.80 & 62.30 & $.1 .32 E .02$ & 0.54 & $1.36 E .02$ & 0.04 \\
\hline 10 & 20.20 & 20.80 & 1.10 & 62.30 & $.1 .32 E .02$ & 2.20 & $1.36 E .02$ & 0.41 \\
\hline 11 & 21.00 & 20.80 & 4.29 & 62.30 & $-1.32 E \cdot 02$ & 0.50 & $1.36 E-02$ & 0.04 \\
\hline 12 & 21.78 & 20.80 & 2.27 & 62.30 & $-1.33 E-02$ & 1.18 & 1.30E.02 & 0.11 \\
\hline 13 & 23.22 & 20.00 & 2.07 & 62.30 & $.1 .33 E .02$ & 1.35 & $1.36 E .02$ & 0.14 \\
\hline 14 & 23.32 & 20.00 & 1.89 & 62.30 & $-1.33 E-02$ & 1.48 & $1.38 E .02$ & 0.17 \\
\hline 15 & 20.64 & 20.00 & 1.56 & 62.30 & $-1.33 E .02$ & 1.58 & $1.36 E .02$ & 0.22 \\
\hline 16 & 19.52 & 21.00 & 1.68 & 62.30 & $-1.33 E .02$ & 1.10 & $1.37 E .02$ & 0.18 \\
\hline 17 & 18.80 & 21.00 & 1.44 & 62.30 & $.1 .33 \mathrm{E} .02$ & 1.57 & 1.37E.02 & 0.23 \\
\hline 18 & 23.00 & 21.00 & 1.60 & 62.30 & $-1.33 \mathrm{E}-02$ & 1.70 & $1.37 \mathrm{E} .02$ & 0.21 \\
\hline 19 & 18.06 & 21.00 & 1.33 & 62.30 & $-1.33 E-02$ & 1.63 & 1.37E.02 & 0.26 \\
\hline 20 & 23.30 & 21.30 & 1.82 & 62.20 & $-1.36 E-02$ & 1.54 & $1.39 E-02$ & 0.18 \\
\hline 21 & 18.14 & 21.30 & 1.07 & 62.20 & $-1.35 E .02$ & 2.04 & 1.39E.02 & 0.40 \\
\hline
\end{tabular}



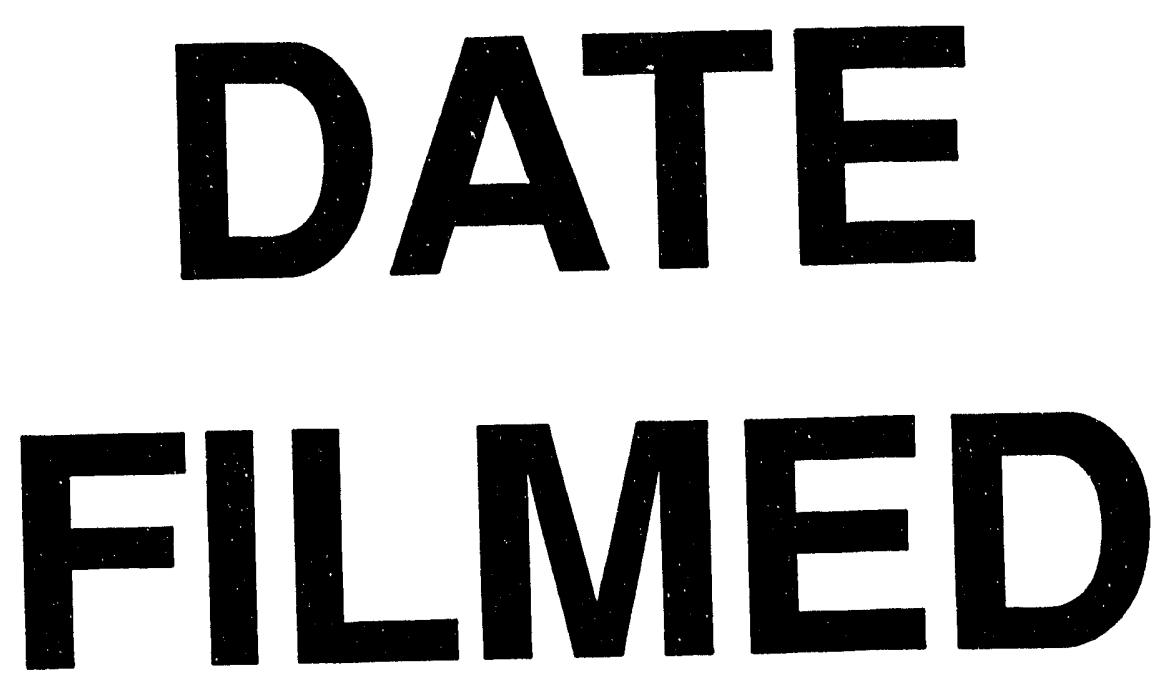

$8 / 4 / 93$
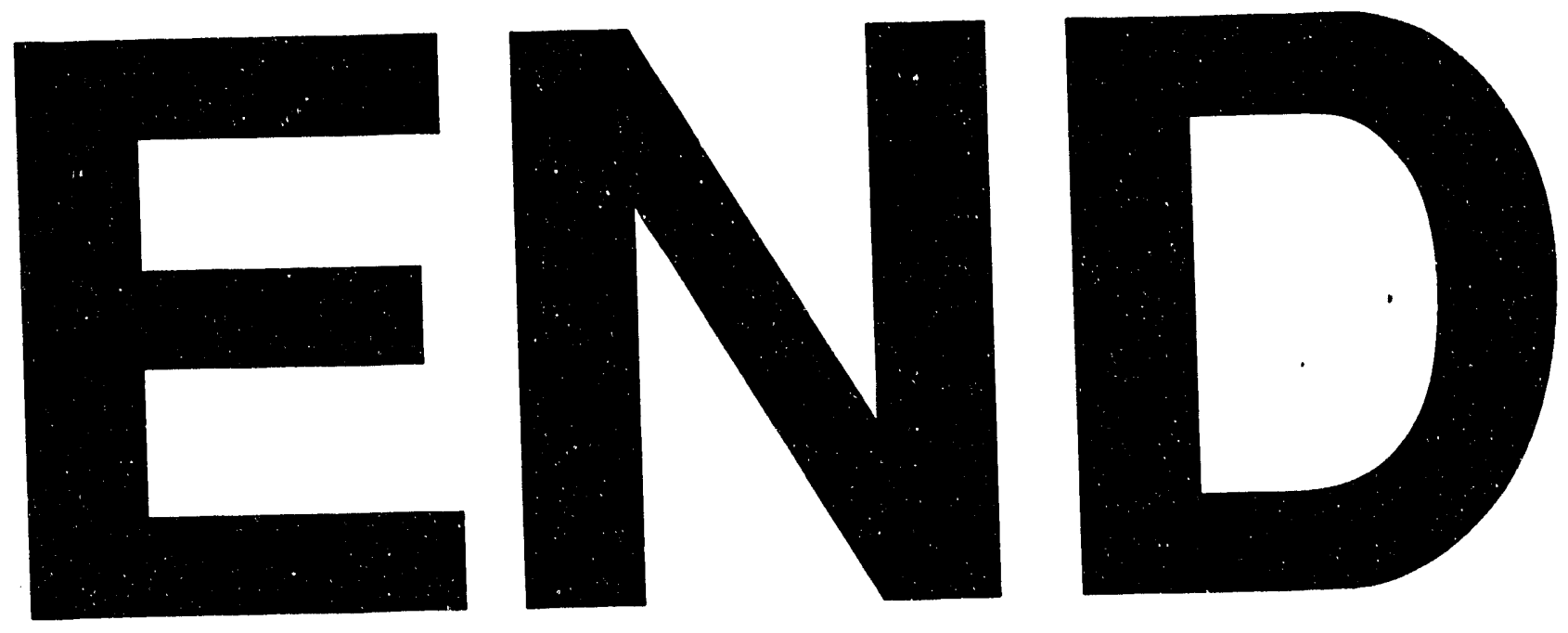


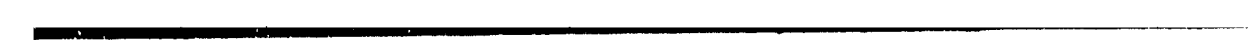

